\title{
Modernizacja i budowa czystego taboru szynowego dla transportu publicznego na terenie miast i na obszarach metropolitalnych
}

\begin{abstract}
Artykut jest poświęcony zagadnieniom zwiazanym z oddziaływaniem na środowisko naturalne taboru szynowego (pojazdów trakcji spalinowej i elektrycznej) eksploatowanego na terenie miast $i$ na obszarach metropolitalnych. Przedstawiono w nim w ujęciu skrótowym typy $i$ rodzaje pojazdów szynowych eksploatowanych $w$ miastach $i$ metropoliach. Omówiono również zagrożenie bezpośrednie i pośrednie, $w$ procesie użytkowania pojazdów szynowych, $w$ tym emisję substancji szkodliwych, hałas $i$ drgania, zanieczyszczenia z otwartych instalacji sanitarnych oraz zanieczyszczenia pochodzqce od materiatów eksploatacyjnych. Podano ponadto przyczyny powstawania zagrożeń oraz możliwe działania do ich obniżenia.

W zakończeniu wskazano na intensyfikacje prac nad budowq nowego oraz modernizacje posiadanego taboru szynowego którego oddziaływanie na środowisko naturalne będzie coraz mniejsze.

(Materiat do artykulu przedstawiono $w$ formie prezentacji na Międzynarodowych Targach Poznańskich - Transporta 2009 - Transport Szynowy XXI wieku dla Polski)
\end{abstract}

\section{Wstęp}

Wzrost świadomości proekologicznej społeczeństw światowych oraz zagrożenia ostatnich dziesięcioleci spowodowane przez tzw. „efekt cieplarniany” przyczynia się do prowadzenia działań mających na celu obniżenie do minimum degeneracji środowiska naturalnego.

Wśród wielu działalności największe zagrożenia stwarzane są przez przemysł (huty, kopalnie, elektrownie), a następnie przez transport przy czym pierwsze miejsce w nim zajmuje transport lądowy. O ile jeszcze niedawno udział transportu szynowego w degradacji środowiska był nieznaczny to obecnie w wyniku rozwoju miast oraz obszarów metropolitalnych ten rodzaj transportu odgrywa również znaczną rolę w emisji substancji szkodliwych do atmosfery. Spowodowane to jest przede wszystkim wzrostem ludnościowym i obszarowym miast i metropoli co z kolei prowadzi do budowy infrastruktury komunikacyjnej (nowych linii transportu szynowego), a więc również systematycznego zwiększenia liczby wdrażanych do eksploatacji pojazdów szynowych trakcji elektrycznej i spalinowej. Do zagrożeń bezpośrednich powodowanych przez eksploatację taboru szynowego należy zaliczyć [2]:

- hałas i drgania

- emisję substancji szkodliwych

- użytkowanie otwartych instalacji sanitarnych

- emisję materiałami i produktami eksploatacyjnymi.

W dalszej części artykułu poszerzymy opis poszczególnych zagrożeń oraz działania mające na celu ich zmniejszenie do minimum, przy czym zajmiemy się tylko zagadnieniami związanymi $\mathrm{z}$ taborem szynowym i ich wpływem na środowisko naturalne oraz taborem użytkowanym i eksploatowanym (nowym i modernizowanym) na terenach miast i obszarów metropolitalnych w Polsce.

Dla lepszego zobrazowania tematyki artykułu kilka definicji wprowadzających:

- miasto - historycznie ukształtowana jednostka osadnicza charakteryzująca się dużą intensywnością, małą ilością terenów rolniczych, ludnością pracującą poza rolnictwem (w przemyśle, usługach, szkolnictwie, administracji, kulturze i sztuce) prowadzącą specyficzny miejski styl życia. W Polsce przyjęto definicję miasta jako jednostki osadniczej o przewadze zwartej zabudowy i funkcjach nierolniczych posiadająca prawa miejskie bądź status miasta nadany w trybie określonym przepisami

- obszar metropolitalny - gęsto zaludniony obszar składający się z kilku lub kilkunastu miast położonych niedaleko znaczącego centrum miejskiego. Miasta te połączone są więzami funkcjonalnymi i ekonomicznymi natomiast miasto (lub miasta) centralne obszaru metropolitalnego tworzy tzw. centrum rozrządowe całego obszaru przez które przebiegają wszystkie linie komunikacyjne. Obszar metropolitalny jest głównym wielofunkcyjnym ośrodkiem danego regionu, w którym skupiają się funkcje wyższego rzędu: ekonomiczne, naukowe i kulturalne. 
We współczesnym świecie, w krajach rozwiniętych, kontakty między regionami następują przede wszystkim poprzez ich obszary metropolitalne, które pozostają ze sobą w powiązaniach komunikacyjnych i instytucjonalnych.

Największe obszary metropolitalne w Polsce to:

- Górnośląski Okręg Przemysłowy (tzw. aglomeracja górnośląska lub śląsko-dąbrowska) $\mathrm{z}$ miastami centralnymi Katowice, Sosnowiec, Gliwice i Bytom otoczonymi miejscowościami satelickimi - Świętochłowice i Lędziny. Obszar ten zamieszkuje kilka milionów mieszkańców

- obszar Warszawy otoczonej kilkunastoma miejscowościami które mogą stać się w przyszłości jej dzielnicami. Obszar ten zamieszkuje ponad 2,5 mln osób.

- obszar Trójmiasta z ośrodkami centralnymi Gdańsk, Gdynia i Sopot oraz kilkunastoma mniejszymi miejscowościami w tym Reda, Rumia, Wejherowo

- obszar Poznania otoczony mniejszymi miejscowościami w tym: Swarzędz, Środa, Śrem, Kórnik, Luboń.

Obszary te oraz miasta jak już wspomniano połączone są ze sobą między innymi więzami komunikacyjnymi, z których na drugim miejscu (po transporcie drogowym) znajduje się transport szynowy wykorzystujący w swojej działalności szereg typów i serii pojazdów w tym pojazdy metra, tramwaje, elektryczne i spalinowe zespoły trakcyjne oraz lekkie pojazdy zwane często autobusami szynowymi.

Większość wykorzystywanego do ruchu taboru szynowego jest przestarzała, a więc stanowiąca w swojej eksploatacji największe zagrożenie dla środowiska.

Dopiero od kilkunastu lat dąży się do odnowy parku pojazdów szynowych poprzez budowę nowego taboru, ale przede wszystkim poprzez jego modernizację.

Budowa nowego taboru szynowego to przede wszystkim cały proces rozpoczynający się opracowaniem koncepcji i założeń, następnie wykonaniem dokumentacji konstrukcyjnej i technicznej (biorąc pod uwage najnowsze rozwiązania, dostępność na rynku, możliwość pełnego recyklingu, minimalne oddziaływanie na środowisko naturalne) wykonaniem prototypu pojazdu i jego przebadaniem $\mathrm{w}$ warunkach stacjonarnych i ruchowych, a kończący się jego wdrożeniem do produkcji i wykorzystaniem do obsługi ruchu pasażerskiego i towarowego.

Natomiast modernizacja taboru szynowego to proces unowocześnienia, uwspółcześnienia pojazdu oraz trwałe jego ulepszanie prowadzące do zwiększenia jego wartości użytkowej.

Najważniejszymi celami modernizacji w odniesieniu do pojazdów szynowych są $[1,5]$ :

- zmniejszenie niekorzystnego oddziaływania na środowisko naturalne

- zmniejszenie (oszczędności) zużycia energii
- podniesienie parametrów technicznych i sprawności oraz gotowości technicznej do wykonywania przewidywanych zadań przewozowych

- ograniczenie kosztów eksploatacji, przeglądów i napraw (zarówno taboru jak i toru)

- podniesienie komfortu i bezpieczeństwa jazdy pasażerów oraz pracy obsługi.

A więc by tabor szynowy wykorzystywany w ruchu miejskim oraz na obszarach metropolitalnych do przewozu pasażerów i ładunków nie stanowił dużego zagrożenia dla środowiska powinien być:

- efektywny energetycznie

- ekonomiczny

- czysty

- wykorzystujący paliwa alternatywne.

Spełnienie w/w celów winno przyświecać zarówno projektantom nowego i modernizowanego taboru szynowego jak również producentom materiałów, aparatów, urządzeń i zespołów oraz wytwórcom energii i paliw.

\section{Przegląd taboru szynowego wykorzystywane- go w kraju w transporcie publicznym na ob- szarach miejskich i na obszarach metropoli- talnych}

W kraju w miastach i w połączeniach między nimi w transporcie szynowym jest wykorzystywanych wiele pojazdów szynowych spalinowych i elektrycznych w tym przede wszystkim:

- pojazdy (pociagi) metra

- tabor tramwajowy

- elektryczne zespoły trakcyjne (w tym autobusy szynowe)

- spalinowe zespoły trakcyjne (w tym autobusy szynowe).

Oczywistym jest, że przez miasta i po obszarach metropolitalnych przejeżdżają również pociagi pasażerskie i towarowe ciagnione lokomotywami, a (w większości dużych miast) do prac manewrowych i przetokowych wykorzystane są najczęściej lokomotywy spalinowe.

Jak już wspomniano większość taboru szynowego eksploatowanego w kraju jest przestarzała wyprodukowana w latach $60 \div 70$-tych ubiegłego wieku. Należy jednak zaznaczyć, że od kilku lat postępuje proces zakupu nowego taboru (widać to zwłaszcza w zakupach nowych tramwaji autobusów szynowych) oraz racjonalnie prowadzona modernizacja.

\subsection{Pojazdy (pociągi) metra}

W Polsce tylko w Warszawie na jednej linii (druga w projekcie) eksploatuje się dwa typy pociagów. Pierwszy z nich serii 81 wyprodukowane zostały przez dwa radzieckie zakłady w Mytiszczi i w Sankt Petersburgu. Natomiast drugi typu Metropolis 98-B wykonano $\mathrm{w}$ koncernie Alstom (w fabryce w Barcelonie i w Chorzowie) [3]. 
Wagony (pojazdy) z byłego Związku Radzieckiego a obecnie z Rosji dostarczone zostały w dwóch seriach:

- wagony 81-717.3 i 81-714.3 - 10 szt. (4 czołowe i 6 środkowych) jako dar w 1989 r.

- wagony 81-572.1 i 81-573.1 - 50 szt. w latach 1994-1997.

Obecnie trwa od 2008r. dostawa trzecia realizowana przez ZAO (Spółka Akcyjna) Wagonmasz z Sankt Petersburga obejmująca 7 kompletów po 6 wagonów typu 81-572.2 i 81-573.2. Nie wchodząc w szczegóły konstrukcyjne (które ze względu na postęp techniczny były nieodzowne) wagony są konstrukcji stalowej $\mathrm{z}$ drzwiami z obu stron. Pudła wagonów opierają się na dwóch wózkach dwuosiowych, z których każdy jest wózkiem trakcyjnym (z zabudowanymi silnikami). Wagony sterownicze (czołowe) wyposażone są w kabiny maszynisty natomiast wagony środkowe na końcach wyposażone są $\mathrm{w}$ wyjścia awaryjne. Wagony czołowe z ostatniej dostawy z Wagonmasz zostały wyposażone również w wyjścia ewakuacyjne na czołach.

Maksymalna prędkość pociagu wynosi $90 \mathrm{~km} / \mathrm{h}$, przy czym ze względów bezpieczeństwa w Metrze Warszawskim ograniczona została do $80 \mathrm{~km} / \mathrm{h}$.

W pierwszych latach eksploatacji wagony łączono w czterowagonowe pociagi natomiast obecnie pociagi złożone są z sześciu wagonów.

Widok pociagu serii 81 (typ 81-572.2 i 81-573.2) z ostatniej dostawy realizowanej przez ZAO Wagonmasz Sankt Petersburg przedstawiono na rys. 1

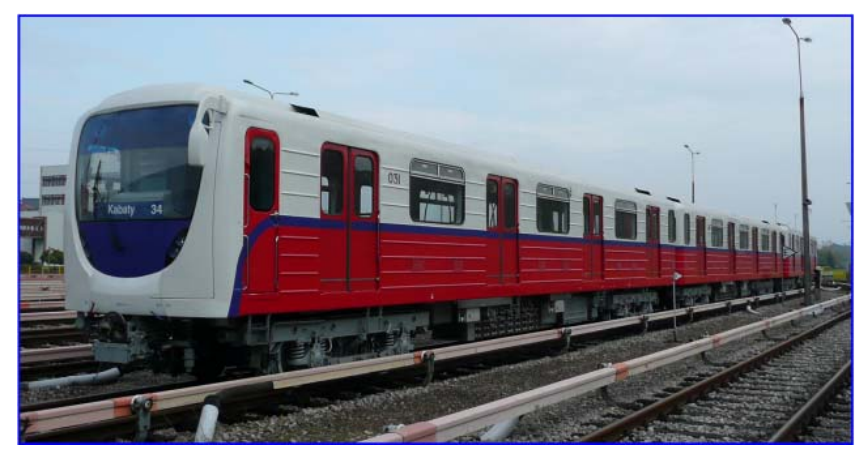

Rys.1 - Pociąg wagonów metra serii 81 produkcji ZAO Wagonmasz

Ze względu na przestarzałą konstrukcję wagonów rosyjskich oraz zwiększonym zapotrzebowaniu na tabor związanym z uruchomieniami dalszych stacji podjęto podjęto decyzję o zakupie wagonów o nowoczesnej konstrukcji spełniających między innymi wymagania ekologiczne.

Dostawę 108 wagonów typu Metropolis-98B realizował w latach $2000 \div 2004$ koncern Alstom. Wagony Metropolis cechuje nowoczesny kształt, przy czym ze względu na duże ich oddziaływanie na podłoże (wywoływane drgania) wymagają szczegółowych przeglądów i częstego toczenia kół. Wagony 98-B są konstrukcji aluminiowo-stalowej, nitowanej, z drzwiami z obu stron. Pudła wagonów posadowione są na dwóch wózkach dwuosiowych przy czym wagony sterownicze z kabiną maszynisty opierają się na wózkach tocznych, natomiast wagony środkowe na wózkach

Podstawowe parametry (dane techniczne) zestawów wagonów metra

Tabela 1

\begin{tabular}{|c|c|c|c|}
\hline Parametr $^{\begin{array}{c}\text { Typ zestawu } \\
\text { (producent) }\end{array}}$ & $\begin{array}{l}\text { Zestaw wagonów metra } \\
\text { typu 81-717.3 i 81-714.3 } \\
\text { (Metrowagonmasz) }\end{array}$ & $\begin{array}{c}\text { Zestaw wagonów me- } \\
\text { tra } \\
\text { typu Metropolis 98-B } \\
\text { (Alstom) }\end{array}$ & $\begin{array}{l}\text { Zestaw wagonów metra } \\
\text { typu 81-572.2 i 81-573.2 } \\
\text { (Wagomasz) }\end{array}$ \\
\hline $\begin{array}{l}\text { Masa służbowa lub max. } \\
{[\mathrm{Mg}]}\end{array}$ & 204 & 280 & 209 \\
\hline $\begin{array}{l}\text { Prędkość max/eksp. } \\
{[\mathrm{km} / \mathrm{h}]}\end{array}$ & $90 / 80$ & $90 / 80$ & $90 / 80$ \\
\hline $\begin{array}{l}\text { Moc zestawu } \\
{[\mathrm{kW}]}\end{array}$ & 2736 & 2880 & 2736 \\
\hline $\begin{array}{l}\text { Długość wagonu / zestawu } \\
{[\mathrm{m}]}\end{array}$ & $19 / 114$ & $19,5 / 116,74$ & $19,21 / 115,26$ \\
\hline $\begin{array}{l}\text { Szerokość nadwozia } \\
{[\mathrm{mm}]}\end{array}$ & 2712 & 2705 & 2712 \\
\hline $\begin{array}{l}\text { Wysokość nadwozia } \\
{[\mathrm{mm}]}\end{array}$ & 3662 & 3660 & 3700 \\
\hline $\begin{array}{l}\text { Wysokość podłogi ponad } \\
\text { główkę szyny [mm] }\end{array}$ & 1208 & 1150 & 1208 \\
\hline 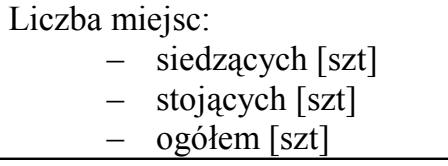 & $\begin{array}{c}240 \\
1320 \\
1560\end{array}$ & $\begin{array}{c}248(+16) \\
1190 \\
1438(+16)\end{array}$ & $\begin{array}{c}256 \\
1604 \\
1860\end{array}$ \\
\hline $\begin{array}{l}\text { Liczba wagonów w zestawie } \\
\text { [szt] }\end{array}$ & 6 & 6 & 6 \\
\hline
\end{tabular}


napędnych. Wagony wyposażone są na czołach w wyjścia bezpieczeństwa.

Wagony Metropolis łączone są w pociagi szeciowagonowe i eksploatowane $\mathrm{z}$ prędkościami maksymalnymi do $80 \mathrm{~km} / \mathrm{h}$.

Widok Metropolis 98-B przedstawiono na rys. 2 natomiast podstawowe parametry techniczne eksploatowanych wagonów zaprezentowano w tabeli 1 .

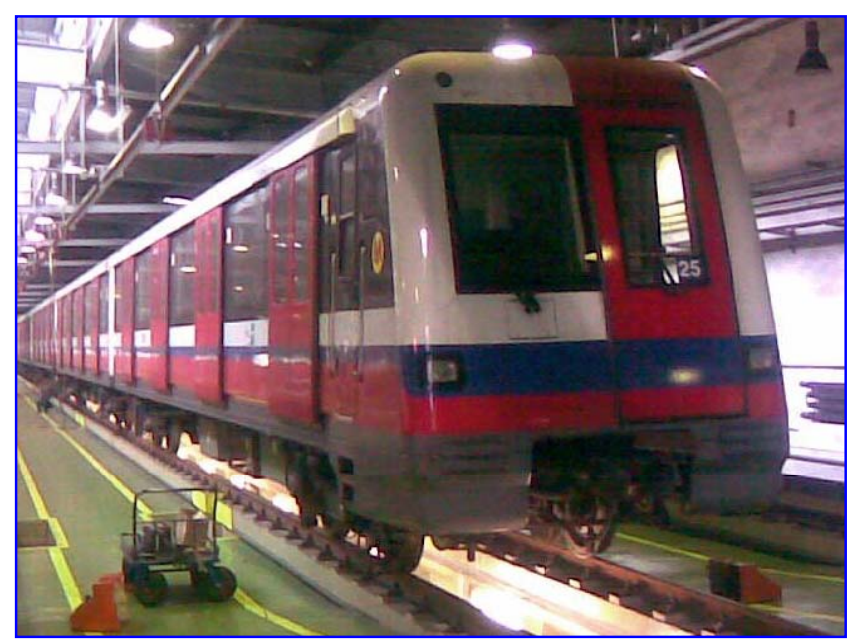

Rys.2 - Pociag wagonów metra typu Metropolis 98-B produkcji konsorcjum Alstom

\subsection{Tabor tramwajowy}

Tabor tramwajowy jest przeznaczony zasadniczo do przewozu osób w miastach oraz jak w przypadku Tramwajów Śląskich i w obszarze Łódzkim tramwaje realizują przewozy pasażerskie między poszczególnymi miastami położonymi w pobliżu miasta centralnego.

Obecnie w Polsce sieć tramwajową posiada czternaście miast, a przewozy realizowane są przez szesnastu przewoźników. Dziewięć sieci tramwajowych jest normalnotorowa $(1435 \mathrm{~mm})$ natomiast pięć posiada tory wąskie o rozstawie $1000 \mathrm{~mm}$.

Zasadnicza konstrukcja tramwaju jednoczłonowego składa się z pudła opartego na ramie i wózkach jezdnych (tocznych i napędnych). Na dachu tramwaju znajduje się odbierak prądu, wywietrzniki, układy wentylacyjno-grzewcze, klimatyzatory, aparaty i urządzenia elektryczne.

Wagon tramwajowy może posiadać jedno lub dwa stanowiska sterownicze. Najczęściej w dwa stanowiska sterownicze są wyposażone tramwaje dwukierunkowe. Z boku pudła znajdują się okna oraz drzwi wejściowe, umieszczone po prawej stronie. Większość urządzeń elektrycznych zabudowanych jest pod ostoją.

Wnętrze wagonu (poza kabiną sterownicza) zajmuje przestrzeń pasażerską wyposażoną w fotele, poręcze, grzejniki. W tylnej części wagonu coraz częściej umieszczony jest dodatkowy pulpit służący do manewrów na terenie zajezdni.
Hamulec tramwaju to najczęściej trzy układy: elektrodynamiczny, szynowy i mechaniczno-elektryczny. W tramwajach (zwłaszcza wieloczłonowych) zastosowano wiele rodzajów wózków tocznych i napędnych.

Różnorodność ich wynika z konstrukcji samych wagonów tramwajowych - niska lub wysoka podłoga, oparcie członów tramwajowych na wózkach typu Jakobsa, na jednym lub dwóch wózkach. Niezależnie wózki napędne wyposażone są w silniki trakcyjne (prądu stałego lub asynchroniczne) zasilane z sieci trakcyjnej o napięciu $600 \mathrm{~V}$. Sposoby przenoszenia napędu na oś są również różnorodne zależnie przede wszystkim od usytuowania silnika trakcyjnego.

W Polsce głównymi dostawcami (producentami) taboru tramwajowego są obecnie:

- Alstom Konstal S.A. (poprzednio Chorzowska Wytwórnia Konstrukcji Stalowych)

- Fabryka Pojazdów Szynowych - H. Cegielski Poznań

- Pojazdy Szynowe „Pesa” Bydgoszcz S.A. Holding.

Ponadto najważniejszymi dostawcami zagranicznymi tramwajów dla zakładów komunikacji miejskiej są między innymi Bombardier, Siemens i Skoda, a w modernizacjach tramwajów starszego typu oprócz w/w zakładów biorą udział Modetrans - Poznań i Protram - Wrocław.

W krajowych zakładach komunikacji miejskiej (miejskie zakłady komunikacyjne, miejskie przedsiębiorstwa komunikacyjne, międzygminna komunikacja tramwajowa) eksploatowanych jest osiemdziesiąt typów wagonów tramwajowych w ilości kilku tysięcy. Stan ten dotyczy zarówno taboru nowego i modernizowanego produkcji krajowej oraz taboru sprowadzonego z zagranicy.

Stan eksploatowanego taboru jest w większości przestarzały, a najbardziej popularną rodziną stanowią tramwaje $105 \mathrm{~N}$ (na tor o prześwicie $1000 \mathrm{~mm}$ oznaczone jako $805 \mathrm{~N}$ ) produkowane w latach $1973 \div$ 2001. Ogółem wyprodukowano ponad 3,5 tys. tych tramwajów w ponad dwudziestu odmianach.

$\mathrm{W}$ ostatnich latach z przyczyn ekonomicznych zakłady komunikacji miejskiej wprowadziły do eksploatacji tramwaje produkowane w latach $50 \div 60$ tych $\mathrm{i}$ najczęściej były one darem miast zachodnich lub zakupywane za symboliczną kwotę. Tramwaje te mimo przestarzałych rozwiązań można spotkać we wszystkich 14 miastach Polski z siecią tramwajową.

Obecnie, biorąc również pod uwagę względy ekonomiczne oraz minimalizowanie zagrożeń ekologicznych większość miast polskich ogłosiło lub ogłosi przetargi na dostawy nowoczesnego najczęściej niskopodłogowego taboru tramwajowego, a ponadto duża część krajowego taboru poddana będzie zabiegom modernizacyjnym. Otrzymywane (zakupione) zarówno od krajowych jak i zagranicznych producen- 
tów tramwaje będą znacznie ekonomiczniejsze, emitujące mniej zanieczyszczeń, cichsze w eksploatacji i łatwiejsze $\mathrm{w}$ utrzymaniu czystości wewnątrz i na zewnątrz.

Ze względu na różnorodność typów tramwajów na rys. $3 \div 11$ przedstawiono wybrane konstrukcje tramwajów najnowocześniejszych eksploatowanych w Polskich miastach. Natomiast w tablicy 2 zaprezentowano ich główne parametry.

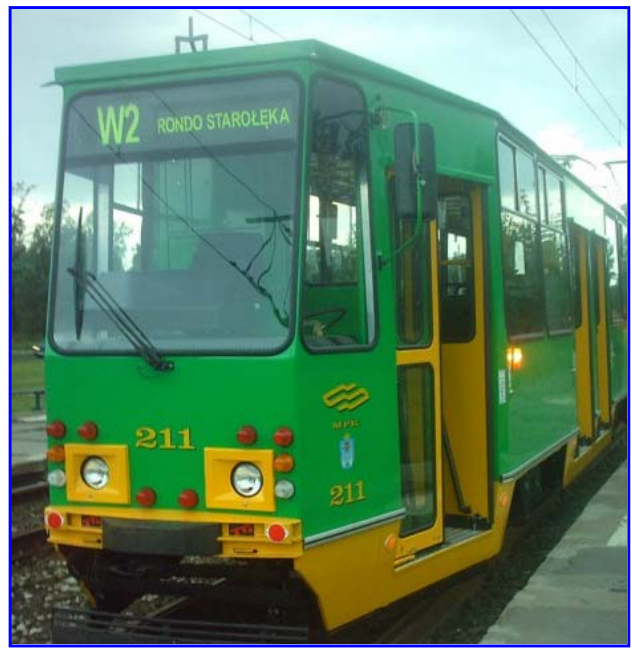

Rys.3 - Tramwaj typu 105 N produkowany w latach $1973 \div 2001$ przez Chorzowski Konstal (najpopularniejszy tramwaj w Polsce)

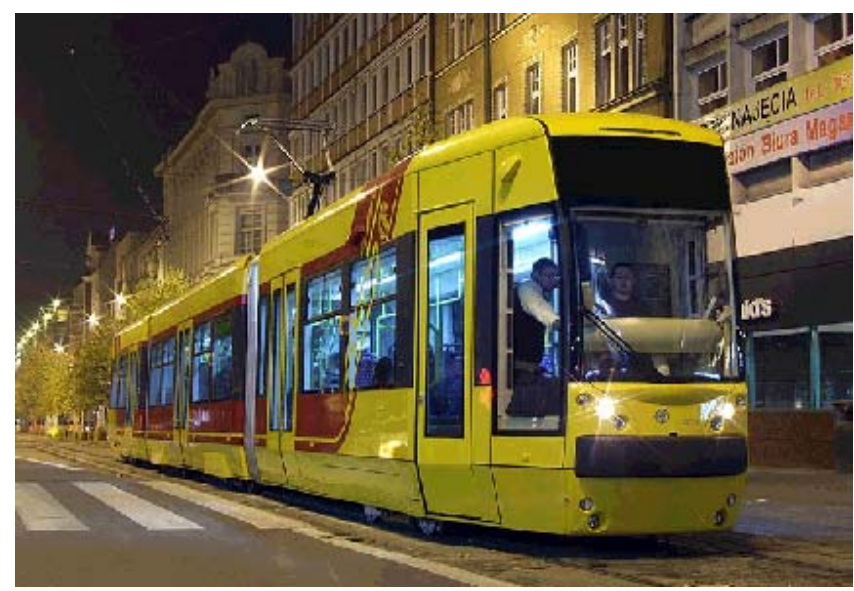

Rys.4 - Tramwaj typu $118 \mathrm{~N}$ niskopodłogowy trójczłonowy produkcji FPS H. Cegielski na ulicach Poznania

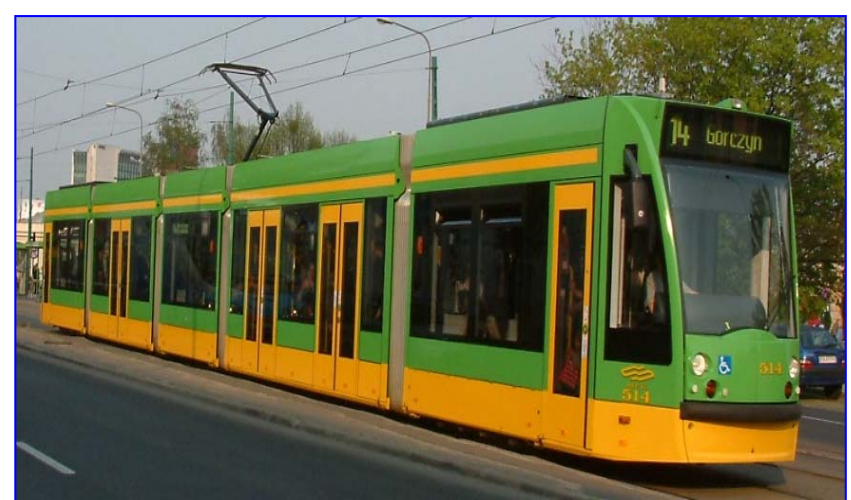

Rys.5 - Tramwaj niskopodłogowy pięcioczłonowy typu RB2 (Combino) produkcji Siemens dla Miejskiego Przedsiębiorstwa Komunikacji Miejskiej w Poznaniu

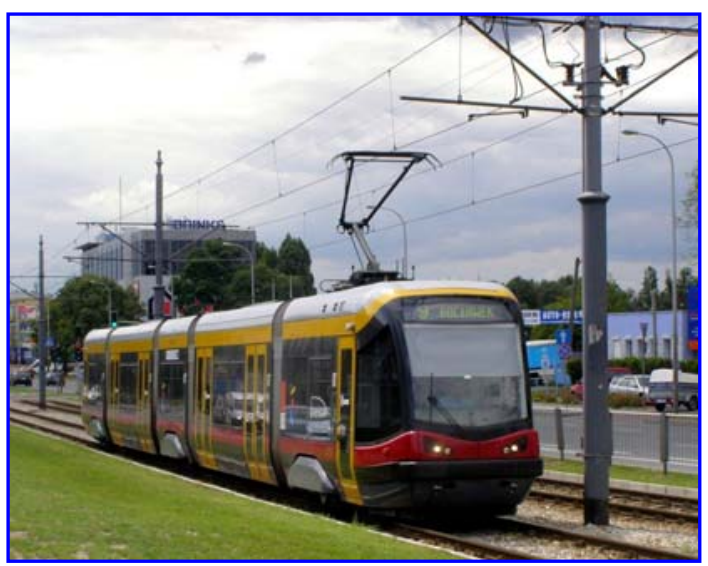

Rys.6 - Tramwaj pięcioczłonowy niskopodłogowy typu 120N produkcji Pesa Bydgoszcz dla Spółki Tramwaje Warszawskie

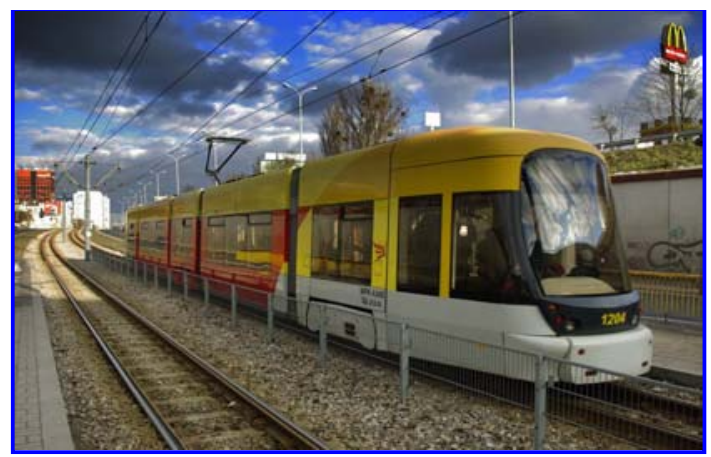

Rys.7 - Tramwaj pięcioczłonowy niskopodłogowy typu Cityrunner produkcji Bomabardier dla Łódzkiego MPK

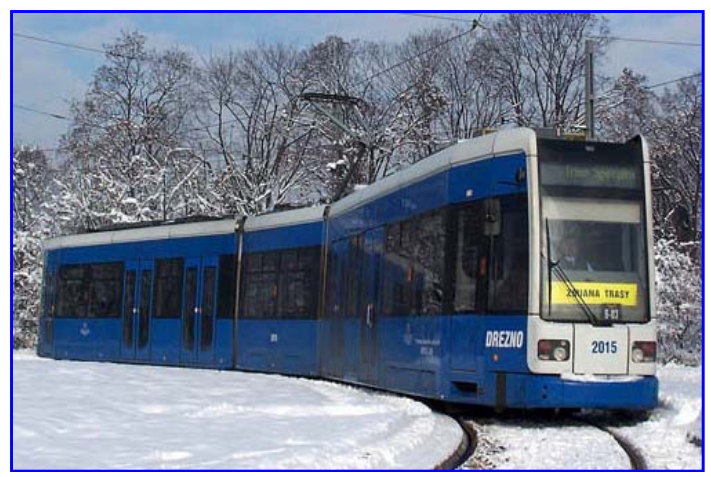

Rys.8 - Tramwaj trójczłonowy niskopodłogowy typu NGT6 produkcji Bombardiera dla MPK Kraków

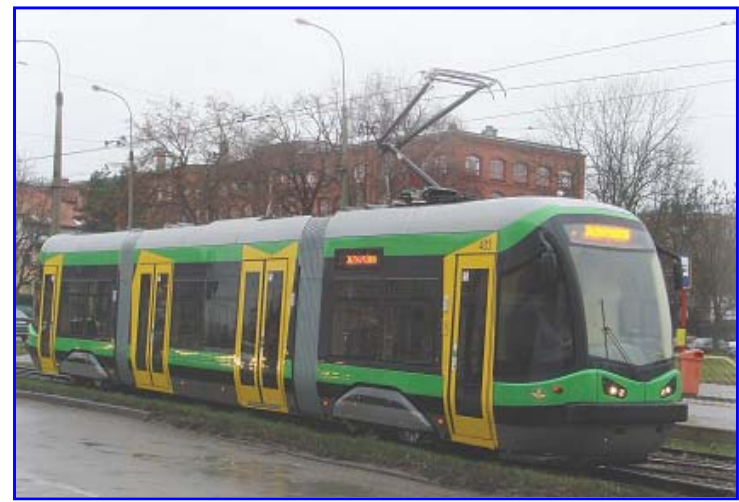

Rys.9 - Tramwaj typu 121N produkcji Pesa Bydgoszcz dla Tramwaji Elbląskich 


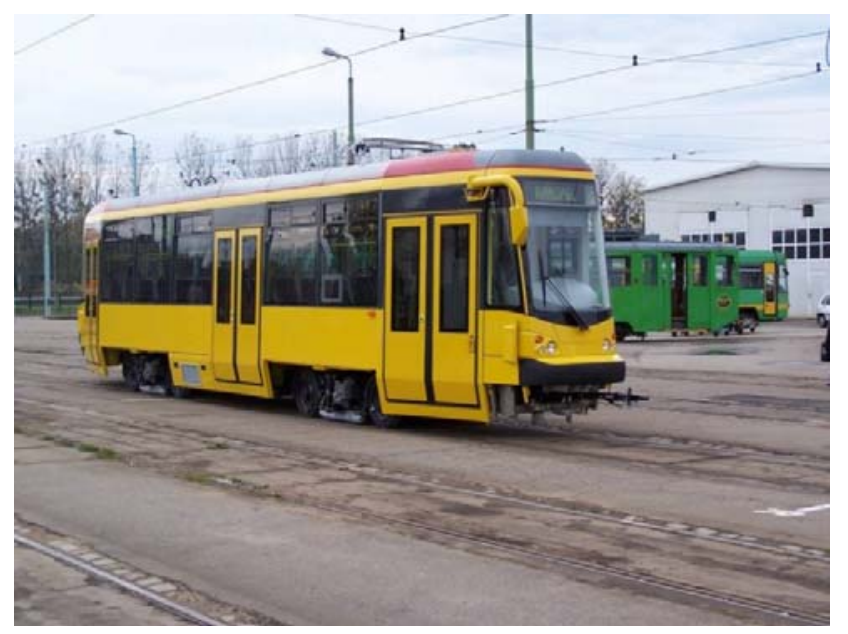

Rys.10 - Tramwaj wysokopodłogowy jednoczłonowy typu 123N produkcji FPS - H. Cegielski dla Spółki Tramwaje Warszawskie

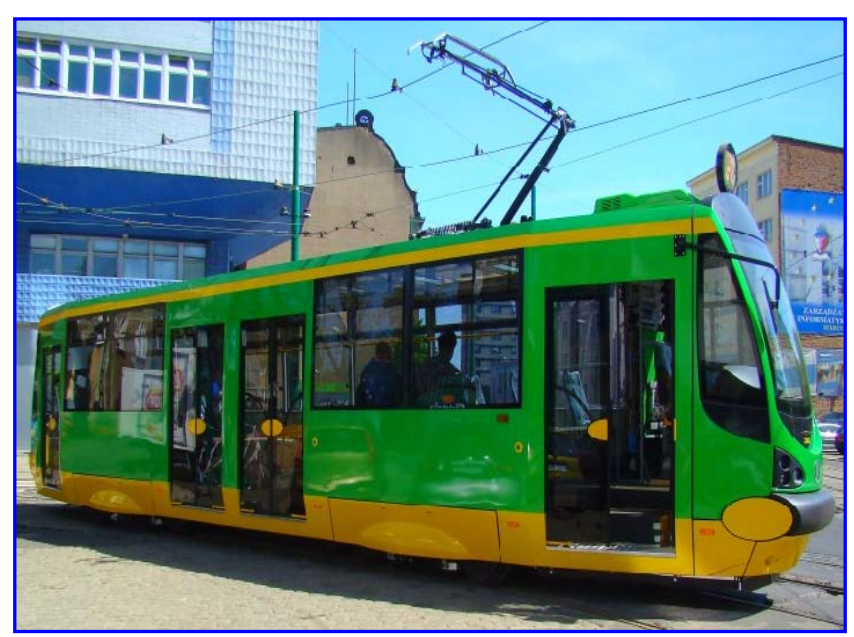

Rys.11 - Zmodernizowany tramwaj jednoczłonowy typu 105N (Moderus Alfa) przez firmę Modetrans dla poznańskiego MPK

Podstawowe parametry wybranych tramwajów:

Tabela 2

\begin{tabular}{|c|c|c|c|c|c|c|c|c|c|}
\hline $\begin{array}{l}\text { Typ tramwaju } \\
\text { producent } \\
\text { Parametry }\end{array}$ & $\begin{array}{c}105 \mathrm{~N} \\
\text { Konstal } \\
\text { Chrzanów }\end{array}$ & $\begin{array}{l}\text { Puma } \\
\text { FPS- } \\
\text { HCP }\end{array}$ & $\begin{array}{l}\text { Com- } \\
\text { bino } \\
\text { Siemens }\end{array}$ & $\begin{array}{c}\text { 120N } \\
\text { Pesa } \\
\text { Byd- } \\
\text { goszcz }\end{array}$ & $\begin{array}{c}\text { Cityrun- } \\
\text { ner } \\
\text { Bombar- } \\
\text { dier }\end{array}$ & $\begin{array}{c}121 N \\
\text { Pesa } \\
\text { Byd- } \\
\text { goszcz }\end{array}$ & $\begin{array}{l}\text { NGT6 } \\
\text { Bombar- } \\
\text { dier }\end{array}$ & $\begin{array}{c}\text { 105N } \\
\text { Mo- } \\
\text { detrans } \\
\text { (moder- } \\
\text { nizacja) }\end{array}$ & $\begin{array}{l}123 N \\
\text { FPS- } \\
\text { HCP }\end{array}$ \\
\hline Długość & 13500 & 24050 & 29200 & 31820 & 29500 & 20220 & 26000 & 13500 & 14300 \\
\hline Szerokość [mm] & 2400 & 2350 & 2400 & 2350 & 2300 & 2350 & 2400 & 2400 & 2354 \\
\hline Wysokość [mm] & 3060 & 3360 & 3640 & 3400 & 3500 & 3400 & 3160 & 3060 & 3340 \\
\hline $\begin{array}{ll}\text { Masa } & {[\mathrm{kg}]}\end{array}$ & 16500 & 29000 & 32380 & 24550 & 34200 & 23500 & 31600 & 17700 & - \\
\hline $\begin{array}{l}\text { Liczba miejsc } \\
\text { siedzacych }\end{array}$ & 20 & 40 & 57 & 63 & 59 & 41 & 76 & 22 & 20 \\
\hline $\begin{array}{l}\text { Liczba miejsc } \\
\text { stojących }\end{array}$ & 105 & 175 & 277 & 148 & 116 & 81 & 152 & 103 & 77 \\
\hline $\begin{array}{l}\text { Liczba miejsc } \\
\text { ogółem }\end{array}$ & 125 & 215 & 334 & 211 & 175 & 122 & 228 & 125 & 97 \\
\hline $\begin{array}{l}\text { Liczba i moc } \\
\text { silników }[\mathrm{kW}]\end{array}$ & $4 \times 41,5$ & $8 \times 55$ & $4 \times 100$ & $4 \times 105$ & $4 \times 100$ & $4 \times 105$ & $4 \times 125$ & $4 \times 40$ & $4 \times 41,5$ \\
\hline
\end{tabular}

\subsection{Elektryczne zespoły trakcyjne}

W przewozach na obszarach metropolitalnych wyposażonych w sieć trakcyjną eksploatowane są najczęściej elektryczne zespoły trakcyjne. Cześś z nich wyprodukowanych przez Fabrykę Wagonów „Pafawag” w latach $1962 \div 1994$ jest obecnie modernizowana. Tylko nieliczne serie są produkcją nową. Należą do nich zespoły Flirt wytwarzane przez firmę Stadler na potrzeby Kolei Mazowieckich i Śląskich oraz zespoły

a)

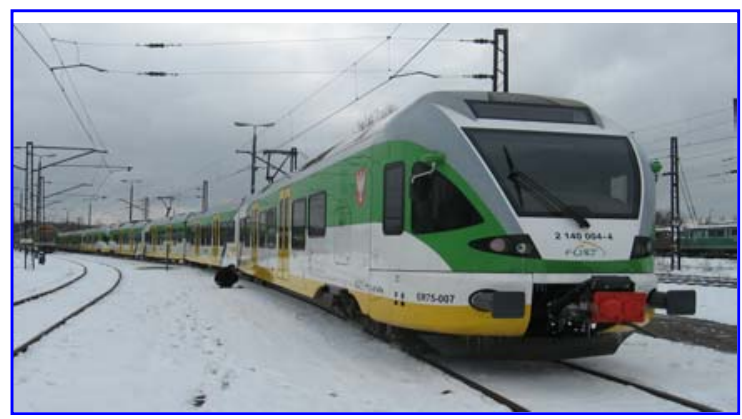

serii EN95 wyprodukowane przez „Pesa” Bydgoszcz dla Warszawskiej Kolei Dojazdowej. Również nowym konstrukcyjnie elektrycznym pojazdem trakcyjnym jest wytworzony przez Pesę Bydgoszcz pierwszy polski elektryczny autobus szynowy serii EN81.

Widoki nowych elektrycznych zespołów trakcyjnych przedstawiono na rys. $12 \div 14$, a ich parametry techniczne w tabelach 3 i 4.

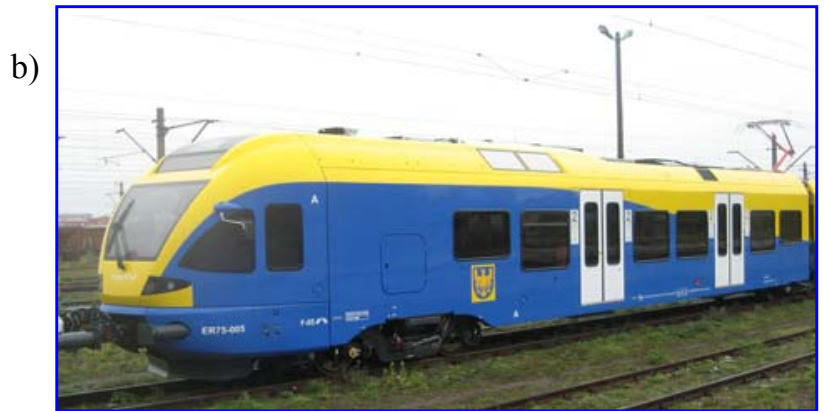

Rys.12 - Elektryczny zespół trakcyjny Flirt Polska: a - dla Kolei Mazowieckich; $\quad$ b - dla Kolei Śląskich (Śląskich Przewozów Regionalnych) 


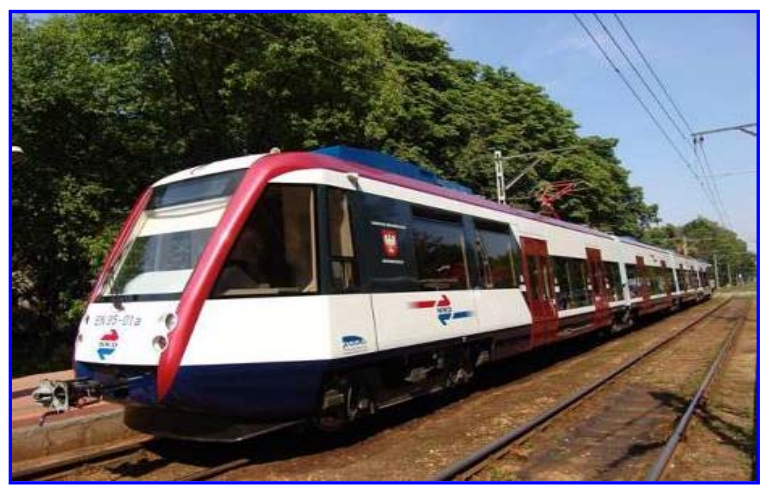

Rys.13 - Elektryczny zespół trakcyjny serii EN93 dla Warszawskiej Kolei Dojazdowej wyprodukowany przez „Pesa” Bydgoszcz

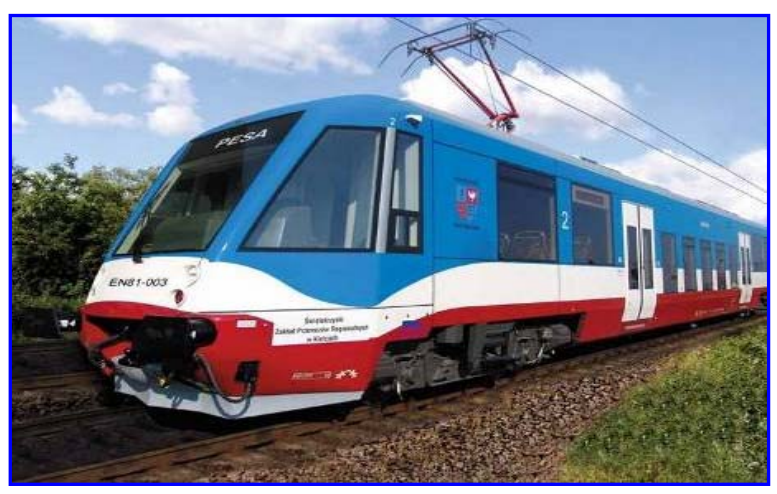

Rys.14 - Elektryczny autobus szynowy serii EN81 produkcji „Pesa” Bydgoszcz

Wybrane parametry elektrycznego zespołu trakcyjnego Flirt - Polska

Tabela 3

\begin{tabular}{|c|c|}
\hline Parametr & Wielkość \\
\hline Zestawienie pojazdu & 4-członowe \\
\hline Max. prędkość jazdy $[\mathrm{km} / \mathrm{h}]$ & 160 \\
\hline Układ osi & $\mathrm{B}_{0}^{\prime}+2+2+2+\mathrm{B}_{0}^{\prime}$ \\
\hline Miejsca siedzące & 183 \\
\hline Siedzenia uchylne & 29 \\
\hline Miejsca siedzące razem z uchylnymi & 212 \\
\hline Miejsca stojące wg DIN 25008, 4 [osób $\left./ \mathrm{m}^{2}\right]$ & 284 \\
\hline Długość zespołu [mm] & 74287 \\
\hline Szerokość pudła [mm] & 2880 \\
\hline Masa $[\mathrm{Mg}]$ & 118 \\
\hline $\begin{array}{l}\text { Masa brutto z obciążeniem miejsc siedzących i stojących wg } \\
\left.\text { DIN } 250084 \text { [osób } / \mathrm{m}^{2}\right]\end{array}$ & 152 \\
\hline Maks. nacisk osi na szynę $[\mathrm{kN}]$ & 171,2 \\
\hline Maksymalna moc na kołach $[\mathrm{kW}]$ & 2200 \\
\hline Moc ciągła na kołach $[\mathrm{kW}]$ & 1600 \\
\hline Maksymalne przyspieszenie rozruchu do $47 \mathrm{~km} / \mathrm{h}\left[\mathrm{m} / \mathrm{s}^{2}\right]$ & 1,01 \\
\hline
\end{tabular}

Główne parametry nowych krajowych elektrycznych zespołów trakcyjnych

Tabela 4

\begin{tabular}{|c|c|c|}
\hline $\begin{array}{rr}\text { Seria zespolu } \\
\text { (układ) }\end{array}$ & $\begin{array}{c}\text { EN 81 } \\
\left(B_{0}+2\right)\end{array}$ & $\begin{array}{c}\text { EN 95 } \\
\left(B_{0}+2+2+B_{0}\right)\end{array}$ \\
\hline Prędkość konstrukcyjna/eksploatacyjna $\quad[\mathrm{km} / \mathrm{h}]$ & $140 / 120$ & $100 / 90$ \\
\hline Masa służbowa/całkowita & $53 / 63$ & $103 / 140,5$ \\
\hline Ilość miejsc siedzących/stojących & $60 / 80$ & $150 / 350$ \\
\hline Moc zespołu napędowego & 560 & 1120 \\
\hline Długość zespołu & 26,53 & 60,00 \\
\hline Szerokość zespołu & 2,85 & 2,85 \\
\hline Wysokość zespołu & 4,005 & 3,93 \\
\hline $\begin{array}{l}\text { Wysokość podłogi } \\
-\quad \text { część niska } \\
-\quad \text { część wysoka } \\
\end{array}$ & $\begin{array}{c}600 \\
1290 \\
\end{array}$ & $\begin{array}{c}600 \\
1125 \\
\end{array}$ \\
\hline Producent & $\begin{array}{c}\text { Pesa } \\
\text { Bydgoszcz }\end{array}$ & $\begin{array}{c}\text { Pesa } \\
\text { Bydgoszcz }\end{array}$ \\
\hline
\end{tabular}

Ostatnie lata to intensywna modernizacja elektrycznych zespołów trakcyjnych serii EN57 i EW60, których większość jest w złym stanie technicznym. Wyprodukowane $\mathrm{w}$ ilości około 1500 szt. były przez czterdzieści lat w nieznacznym zakresie modyfikowane i modernizowane.
Program modernizacji był i jest realizowany przez największe zakłady taboru kolejowego, tj. „Pesa” Bydgoszcz, „Newag” Nowy Sącz oraz Zakłady Naprawcze Taboru Kolejowego „Mińsk Mazowiecki”. 
Zakres modernizacji był bardzo szeroki i obejmował zarówno poprawę stylistyki (wyglądu zewnętrznego) jak i wymianę przestarzałych aparatów, urządzeń i zespołów. Również użyte w budowie materiały cechują się niepalnością oraz możliwością ich powtórnego wykorzystania (recyklingu).

$\mathrm{Z}$ punktu widzenia oddziaływanie na środowisko naturalne (mniejsze zagrożenie bezpośrednie w eksploatacji) w zmodernizowanych zespołach wprowadzono $[1,4]$ :

- rozruch impulsowy współpracujący z hamowaniem dynamicznym

- nowy układ współpracy hamulca pneumatycznego z hamulcem dynamicznym

- nowy układ odsprężynowania zestawów kołowych za pośrednictwem elementów elastycznych oraz nowy układ hamulca postojowego

- nową sprężarkę śrubową oraz przetwornicę statyczną

- ekologiczne kabiny sanitarne pracujące w obiegu zamkniętym

- system ogrzewania nawiewnego o mniejszym zużyciu energii oraz system klimatyzacji kabin sterowniczych.

W ostatniej serii zmodernizowanych zespołów (oznaczenie EN57 AKM) wprowadzono asynchroniczne silniki trakcyjne oraz zmieniono systemy sterowania i diagnozowania.

Ogółem zmodernizowano kilkadziesiąt zespołów trakcyjnych serii EN57 zarówno w ramach Sektorowego Programu Operacyjnego „Transport” finansowanego w dużej części ze środków unijnych oraz na potrzeby Kolei Mazowieckich, PKP Przewozy Regionalne, Szybkiej Kolei Miejskiej w Warszawie i Trójmieście oraz dwa zespoły serii EW60 na potrzeby przewozowe Kolei Mazowieckich.

Widoki zmodernizowanych zespołów EN57 i EW60 przedstawiono na rys. $15 \div 20$, a ich główne parametry techniczne w tabeli 5 .

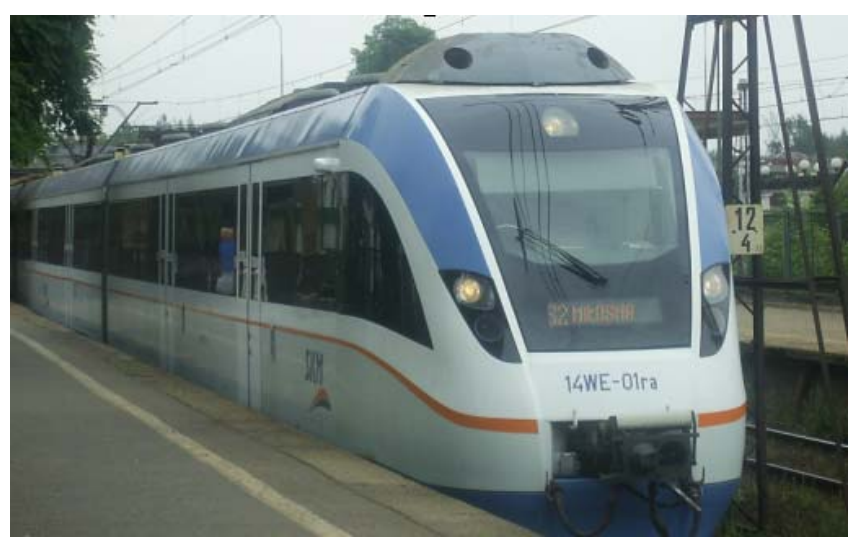

Rys.15 - Elektryczny zespół trakcyjny typu 14WE (na bazie EN57) zmodernizowany przez „Newag” Nowy Sącz dla SKM Warszawa

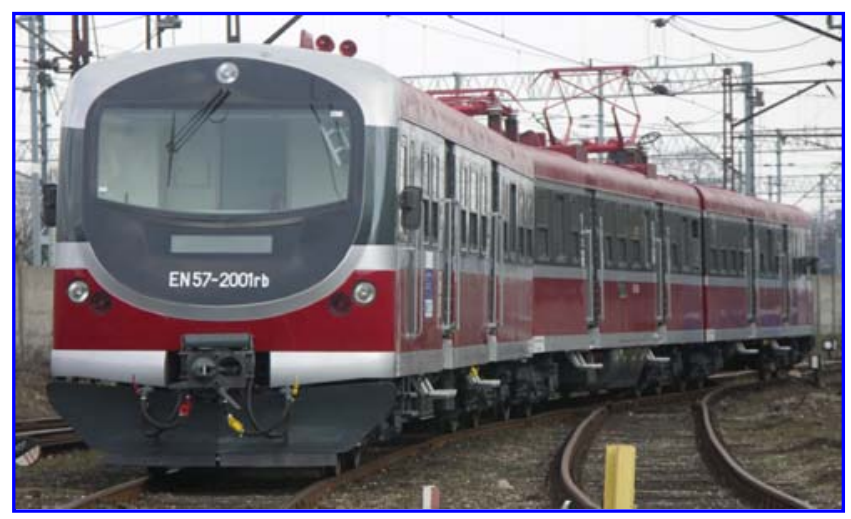

Rys.16 - Zmodernizowany elektryczny zespół trakcyjny EN57 SPOT dla PKP Przewozy Regionalne

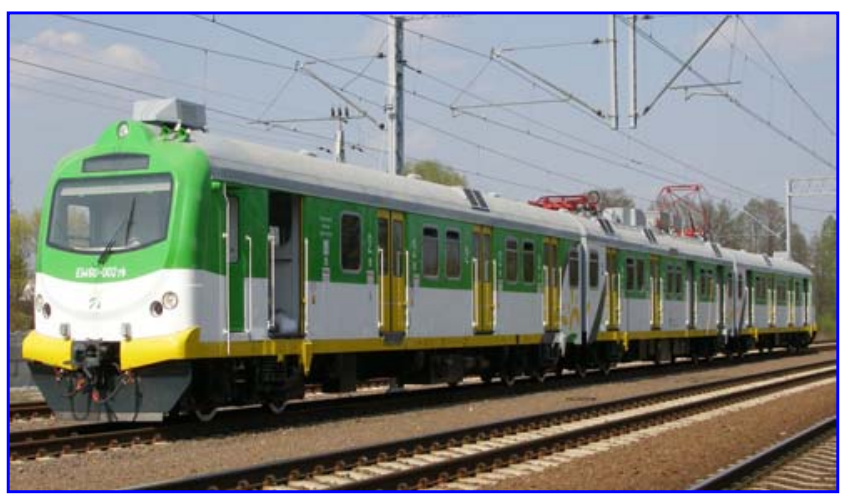

Rys.17 - Elektryczny zespół trakcyjny EW60(6WEb) zmodernizowany dla Kolei Mazowieckich

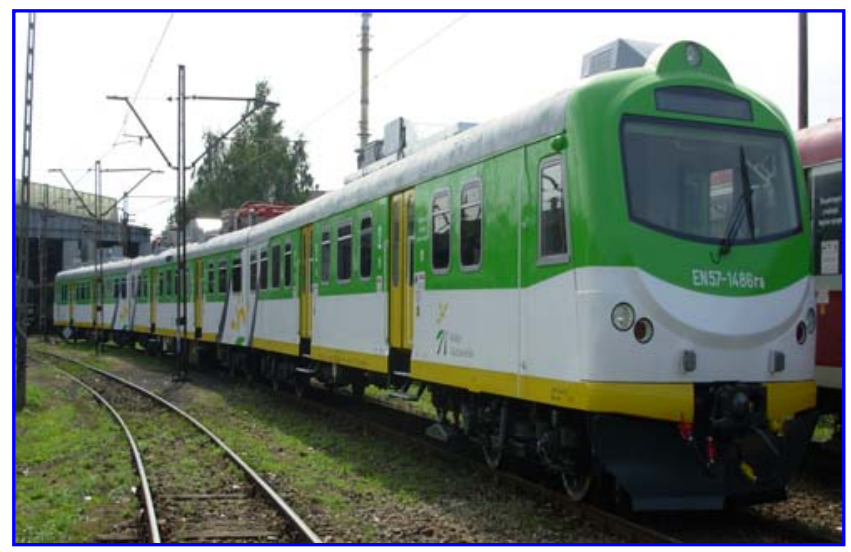

Rys.18 - Zmodernizowany elektryczny zespół trakcyjny EN57 KM dla Kolei Mazowieckich

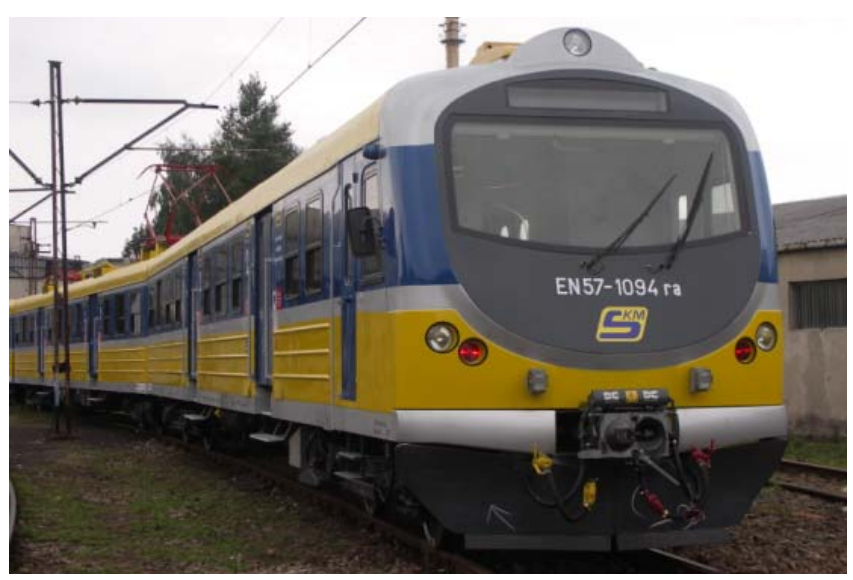

Rys.19 - Zmodernizowany elektryczny zespół trakcyjny EN57 SKM dla Szybkiej Kolei Miejskiej w Trójmieście 
Parametry techniczne zmodernizowanych elektrycznych zespołów trakcyjnych

Tabela 5

\begin{tabular}{|c|c|c|c|c|c|}
\hline $\begin{array}{lr}\text { Seria lub } \\
\text { typ ezt }\end{array}$ & $14 \mathrm{WE}$ & $\begin{array}{c}\text { EW 60 } \\
\text { (6WEb) }\end{array}$ & $\begin{array}{c}\text { EN57 KM } \\
(5 B k+6 B k+5 B k)\end{array}$ & $\begin{array}{c}\text { EN57 SKM } \\
(5 B k+6 B k+5 B k)\end{array}$ & $\begin{array}{c}\text { EN57 AKM } \\
(5 B k+6 B k+5 B k)\end{array}$ \\
\hline Masa służbowa/całkowita $[\mathrm{Mg}]$ & $125 / 165$ & $129 / 170$ & $125 / 170$ & $125 / 170$ & $125 / 170$ \\
\hline $\begin{array}{ll}\text { Prędkość } & {[\mathrm{km} / \mathrm{h}]}\end{array}$ & 110 & 100 & 110 & 110 & 120 \\
\hline $\begin{array}{cl}\text { Liczba } & \text { miejsc } \\
- & \text { siedzących } \\
- & \text { stojących } \\
- & \text { ogółem }\end{array}$ & $\begin{array}{l}192 \\
250 \\
442\end{array}$ & $\begin{array}{l}147 \\
430 \\
577\end{array}$ & $\begin{array}{l}188 \\
468 \\
656\end{array}$ & $\begin{array}{l}158 \\
498 \\
656\end{array}$ & $\begin{array}{l}188 \\
468 \\
656\end{array}$ \\
\hline Moc & 608 & 824 & 580 & 580 & 1000 \\
\hline Długość zespołu & 66 & 64,84 & 64,615 & 64,615 & 64,615 \\
\hline Szerokość drzwi & 1300 & 1180 & 1180 & 1180 & 1180 \\
\hline $\begin{array}{l}\text { Wysokość podłogi ponad głów- } \\
\text { ką szyny } \\
\mathrm{mm}]\end{array}$ & 1150 & 1150 & 1150 & 1150 & 1150 \\
\hline Zakład modernizujący zespół & $\begin{array}{l}\text { Newag } \\
\text { Nowy } \\
\text { Sacz }\end{array}$ & $\begin{array}{c}\text { ZNTK } \\
\text { Mińsk Ma- } \\
\text { zowiecki }\end{array}$ & $\begin{array}{l}\text { ZNTK } \\
\text { Mińsk Mazo- } \\
\text { wiecki }\end{array}$ & $\begin{array}{l}\text { ZNTK } \\
\text { Mińsk Mazo- } \\
\text { wiecki }\end{array}$ & $\begin{array}{l}\text { ZNTK } \\
\text { Mińsk Mazo- } \\
\text { wiecki }\end{array}$ \\
\hline
\end{tabular}

\subsection{Spalinowe zespoły trakcyjne (autobusy szy- nowe)}

Spalinowe zespoły trakcyjne w tym lekkie pojazdy szynowe zwane często „autobusami szynowymi” eksploatowane są na obszarach metropolitalnych na liniach drugorzędnych niezelektryfikowanych. Zdecydowana większość tych pojazdów budowana w ostatnim okresie to pojazdy nowoczesne cechujące się minimalnie szkodliwym oddziaływaniem na środowisko naturalne.

Należą do nich:

- autobusy jedno- i dwuczłonowe serii SA105 $(213 \mathrm{M}$ i $213 \mathrm{Ma})$ i SA108 $(215 \mathrm{M})$ produkcji Poznańskich Zakładów Naprawczych Taboru Kolejowego

- autobusy jedno- i dwuczłonowe serii SA107 (211M) i SA109 (212M) produkcji Kolejowych Zakładów Mechanicznych „Kolzam” w Raciborzu

- autobusy jednoczłonowe SA106 (214M, $214 \mathrm{Ma}, 214 \mathrm{Mb})$ oraz dwuczłonowe SA131, SA132, SA133, SA134, SA138 (218M, 218Ma, $218 \mathrm{Mb})$ produkcji „Pesa” Holding S.A. w Bydgoszczy.

Pozostałe serie autobusów wyprodukowane wcześniej przez ZNTK w Poznaniu i „Kolzam” Racibórz w ilości kilkunastu sztuk są konstrukcjami przestarzałymi jednak nie stanowią dużego zagrożenia dla krajowego środowiska naturalnego, nie mniej jednak należałoby się zastanowić nad ich modernizacją lub co najmniej remotoryzację, tj. wymianę przestarzałych silników spalinowych i przekładni względnie zastosowanie w eksploatacji alternatywnych paliw gazowych, ciekłych i syntetycznych.

Największe zagrożenie dla środowiska naturalnego stwarzają jednak pojazdy przestarzałe sprowadzane do kraju zarówno przez spółkę PKP (Przewozy Regionalne) jak i przez prywatnych operatorów kolejo- wych. Również w ruchu przygranicznym (na zachodzie i południu) mogą pojawić się spalinowe zespoły trakcyjne i autobusy szynowe nie spełniające wymagań w zakresie emisji substancji szkodliwych, a ponadto eksploatowane na liniach zelektryfikowanych, na których winny być użytkowane bardziej ekologiczne pojazdy trakcji elektrycznej, a więc elektryczne zespoły trakcyjne $i$ autobusy szynowe.

Do starszego typu spalinowych zespołów trakcyjnych i spalinowych autobusów szynowych sprowadzanych $\mathrm{z}$ zagranicy (po wycofaniu $\mathrm{z}$ ruchu rodzimych przewoźników) należą $[5,6]$ :

- spalinowe zespoły trakcyjne dwu- i trójczłonowe serii SA110 (VT624 + VM928) eksploatowane wcześniej przez Koleje Niemieckie na trasie Berlin-Szczecin, a zakupione przez PKP Przewozy Regionalne województwa zachodniopomorskiego

- spalinowe zespoły trakcyjne jednoczłonowe typu VT627 i dwuczłonowe typu VT628 produkcji niemieckiej zakupione i eksploatowane przez Koleje Mazowieckie

- spalinowe zespoły trakcyjne dwuczłonowe serii MR/MRD i wieloczłonowe mogące pracować w zestawach od dwu- do siedmioczłonowych serii Y produkowane przez niemiecką firmę Wagonnfabrik Uerdingen eksploatowane przez Duńskie Koleje Państwowe, a obecnie eksploatowane przez prywatnego operatora Kolejowego - PCC - Arriva

- spalinowe zespoły trakcyjne jednoczłonowe serii DH1 i dwuczłonowe serii DH2 produkcji niemieckiej (eksploatowane wcześniej przez Holenderskie Koleje Państwowe) obecnie doposażane przez Poznańskie Zakłady Naprawcze Taboru Kolejowego z przeznaczeniem na potrzeby eksploatacyjne powstających Kolei Regionalnych i prywatnych operatorów 
- spalinowe zespoły trakcyjne VT642 cechujące się nowoczesnymi rozwiązaniami oraz silnikiem spełniającym wymagania $\mathrm{w}$ zakresie emisji substancji szkodliwych do atmosfery jednakże eksploatowane na trasie Berlin-Wrocław posiadających sieć trakcyjną. $Z$ przeprowadzonego rozeznania $\mathrm{w}$ warunkach eksploatacyjnych Kolei Niemieckich nie jest zalecana eksploatacja pojazdów spalinowych na liniach zelektryfikowanych.

Należy więc dążyć do tego, aby spalinowe zespoły trakcyjne sprowadzone z zagranicy lub wjeżdżające na tory Polskich Linii Kolejowych były przede wszystkim młodsze wiekiem, nowoczesne i w minimalnym stopniu oddziaływały na środowisko naturalne. Ponadto pojazdy takiego typu winny być przed uzyskaniem dopuszczenia do eksploatacji w Polsce szczegółowo badane biorąc pod uwagę również zdolności do recyklingu i utylizacji po zakończonej eksploatacji.

Widoki autobusów szynowych produkcji krajowej, które $\mathrm{w}$ minimalnym stopniu degeneruja środowisko naturalne przedstawiono na rys. $20 \div 25$, a ich wybrane parametry techniczne w tabeli 6 .

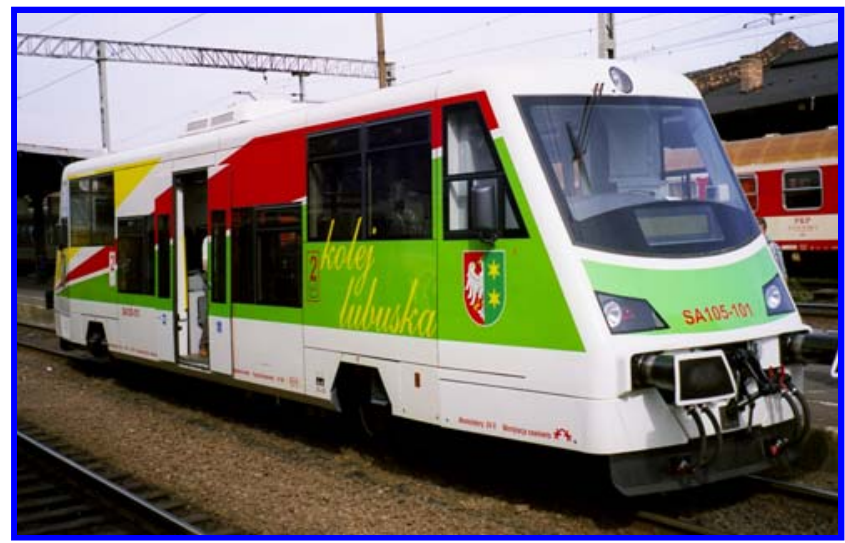

Rys.20 - Autobus szynowy jednoczłonowy serii SA105 (213M) produkcji Poznańskich Zakładów Taboru Kolejowego na potrzeby Kolei Lubuskiej

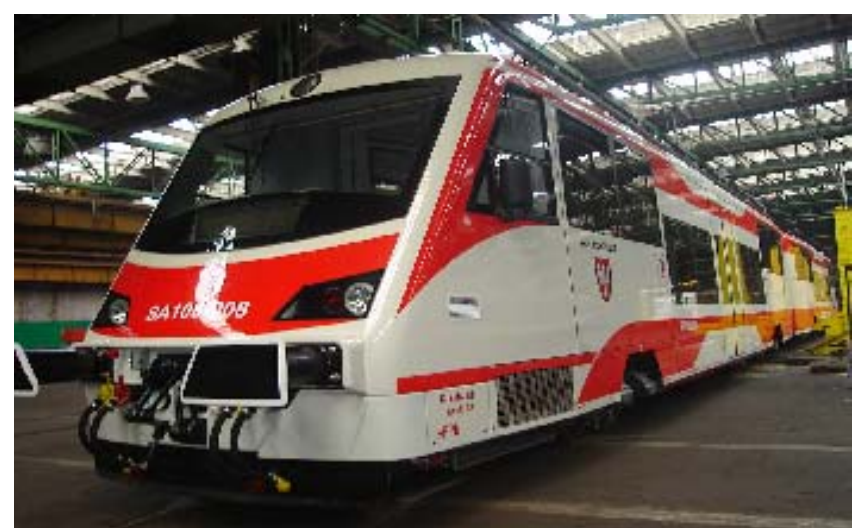

Rys.21 - Autobus szynowy dwuczłonowy serii SA108 (215M) produkcji ZNTK Poznań dla PKP Przewozy Regionalne

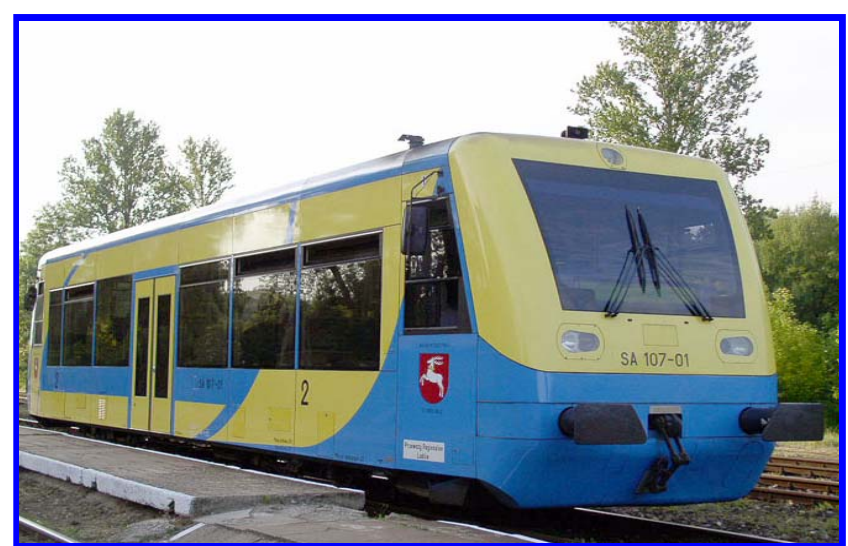

Rys.22 - Autobus szynowy jednoczłonowy serii SA107 (211M) produkcji Kolzam Racibórz

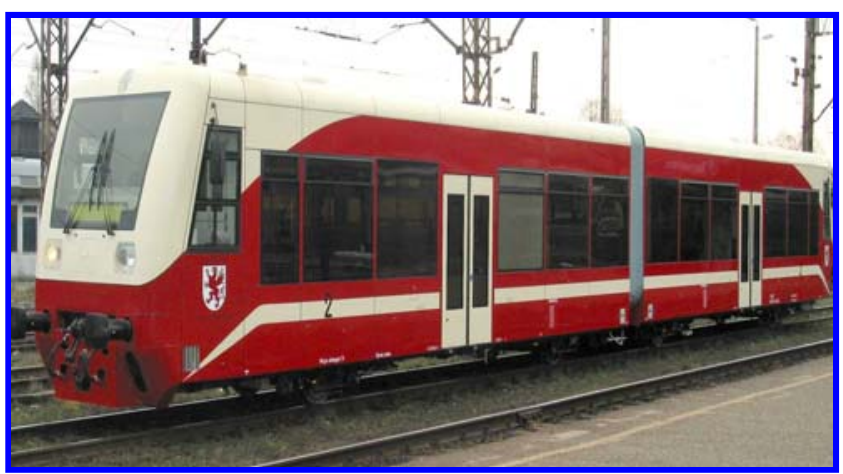

Rys.23 - Autobus szynowy dwuczłonowy serii SA108 (212M) produkcji Kolzam Racibórz

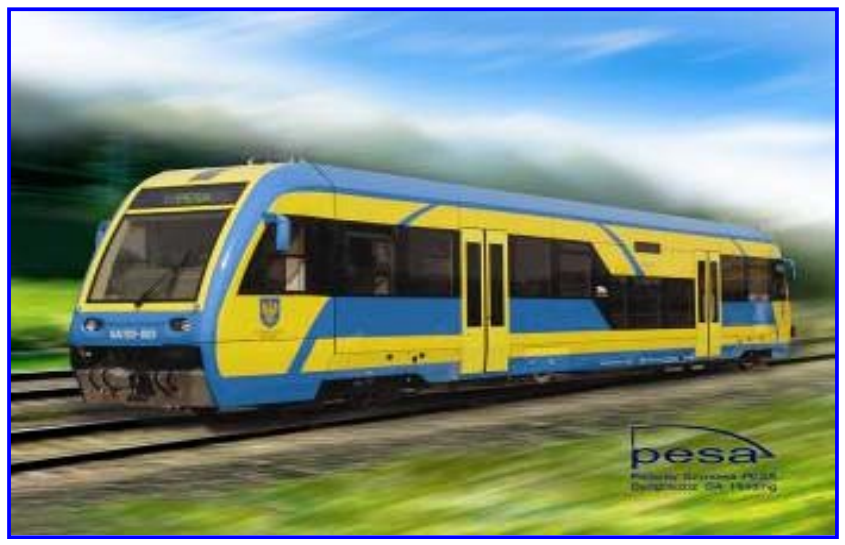

Rys.24 - Jednoczłonowy autobus szynowy serii SA106 (214M) produkcji Pesa Bydgoszcz

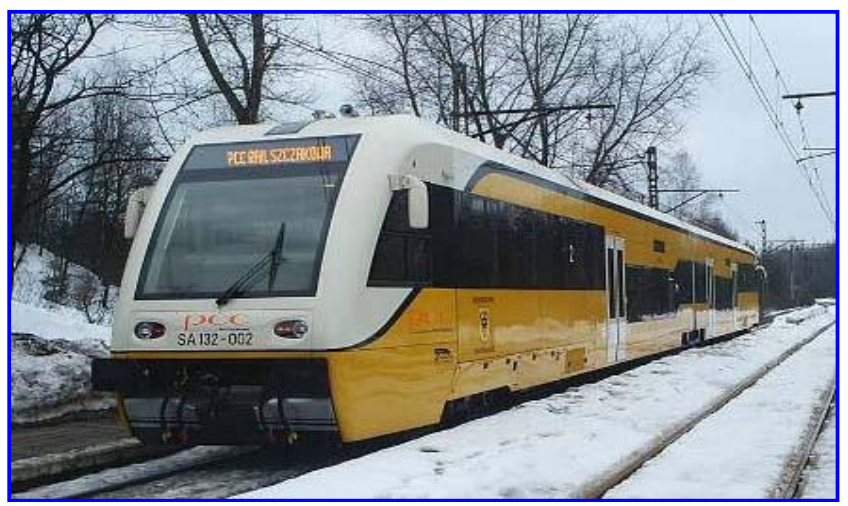

Rys.25 - Dwuczłonowy autobus szynowy serii SA133 (218M) produkcji Pesa Bydgoszcz 
Wybrane parametry najnowszych lekkich pojazdów szynowych (autobusów szynowych) eksploatowanych na obszarach miejskich i w obszarach metropolitalnych

Tabela 6

\begin{tabular}{|c|c|c|c|c|c|c|}
\hline \begin{tabular}{|ll} 
Parametr & Seria (typ) \\
\end{tabular} & $\begin{array}{l}\text { SA107 } \\
(211 M) \\
\end{array}$ & $\begin{array}{l}\text { SA109 } \\
(212 M) \\
\end{array}$ & $\begin{array}{r}\text { SA105 } \\
(213 M) \\
\end{array}$ & $\begin{array}{l}\text { SA108 } \\
(215 M) \\
\end{array}$ & $\begin{array}{r}\text { SA106 } \\
(214 M) \\
\end{array}$ & $\begin{array}{c}\text { SA131 } \div \text { SA134 } \\
(218) \\
\end{array}$ \\
\hline Układ osi & $\mathrm{A}+1$ & $\mathrm{~A}+1-1+\mathrm{A}$ & $\mathrm{A}+1$ & $A+1-1+A$ & $\mathrm{~B}+2$ & $\mathrm{~B}+2-2+\mathrm{B}$ \\
\hline Prędkość max/ekspl. $\quad[\mathrm{km} / \mathrm{h}]$ & $120 / 90$ & $120 / 90$ & $110 / 90$ & $110 / 90$ & $140 / 120$ & $140 / 120$ \\
\hline Ilość miejsc siedzących/stojących & $41 / 50$ & $70 / 100$ & $38 / 52$ & $94 / 101$ & $70 / 60$ & $140 / 130$ \\
\hline Moc $\quad[\mathrm{kW}]$ & 225 & $2 \times 225$ & 257 & $2 \times 257$ & 390 & $\begin{array}{c}2 \times 360 \\
\text { lub } 2 \times 382\end{array}$ \\
\hline Masa służbowa/całkowita $[\mathrm{Mg}]$ & $24 / 31$ & $46 / 60$ & $28 / 35$ & $56 / 71$ & $51 / 60$ & $80 / 98$ \\
\hline $\begin{array}{l}\text { Max. nacisk zestawu kołowego na } \\
\text { tor }\end{array}$ & 160 & 160 & 160 & 160 & 160 & 160 \\
\hline Producent & $\begin{array}{l}\text { Kolzam } \\
\text { Racibórz }\end{array}$ & $\begin{array}{l}\text { Kolzam } \\
\text { Racibórz }\end{array}$ & $\begin{array}{l}\text { ZNTK } \\
\text { Poznań }\end{array}$ & $\begin{array}{l}\text { ZNTK } \\
\text { Poznań }\end{array}$ & $\begin{array}{c}\text { Pesa } \\
\text { Bydgoszcz }\end{array}$ & $\begin{array}{c}\text { Pesa } \\
\text { Bydgoszcz }\end{array}$ \\
\hline
\end{tabular}

3. Zagrożenia środowiska naturalnego od strony taboru szynowego $w$ ruchu miejskim i na obszarach metropolitalnych

Budowa nowego i modernizacja eksploatowanego taboru dla transportu publicznego powinna być związana przede wszystkim z takim doborem aparatów, urządzeń i zespołów, a przede wszystkim materiałów które zapewniają $\mathrm{z}$ jednej strony minimalne zużycie energii na jego wytworzenie (modernizację) z drugiej natomiast zapewnią utrzymanie czystości podczas całego procesu eksploatacji.

Ważnym jest również by po zakończeniu eksploatacji większość materiałów użytych w budowie lub modernizacji można by poddać recyklingowi, a materiały poddawane utylizacji nie powodowały dalszego skażenia środowiska.

O czystości taboru możemy mówić w sensie:

- czystości wewnętrznej

- czystości zewnętrznej

- czystości w ujęciu ekologicznym.

Czystość wewnętrzna i zewnętrzna związana jest przede wszystkim $\mathrm{z}$ doborem materiałów podczas projektowania oraz takim kształtowaniem wewnętrznym i zewnętrznym pojazdu szynowego by energia i środki zużyte na ich utrzymanie były minimalne. Chodzi tu przede wszystkim o zużycie energii i środków myjących na utrzymanie porządku wewnętrznego i zewnętrznego.

Należy więc dążyć do użycia materiałów wytrzymałych mechanicznie i odpornych na zabrudzenia w wyłożeniach i pokryciach podłóg, ścian i sufitów; stosowania na siedzenia $i$ inne elementy wewnętrzne materiałów niepalnych, nietoksycznych, a przede wszystkim wandaloodpornych. W projektowaniu wnętrz należy unikać ostrych kantów, krawędzi, połączeń, które nie służą w utrzymaniu czystości i porząd$\mathrm{ku}$.

Zewnętrzna konstrukcja zwłaszcza nadwozi winna być wykonana najlepiej z lekkich wytrzymałych materiałów o wysokiej wytrzymałości i odporności na korozję. Ponadto kształty pojazdów winny być opływowe, a do pokrycia należy stosować farby ekologiczne zawierające środki utrudniające niszczenie, tj. środki ,antygrafiti”.

Ważnym jest również to, by stosowane były szyby odporne na zniszczenie o wysokiej wytrzymałości mechanicznej.

W/w kilka przykładów, w przypadku ich stosowania na pewno będą miały pozytywne znaczenie zarówno dla środowiska jak i dla ekonomii przedsiębiorstw eksploatujących tabor szynowy.

Czystość taboru szynowego może być:

- bezpośrednia

- pośrednia.

Czystość bezpośrednia oznacza, że jej skutki będa odczuwalne w miejscu jego eksploatacji, natomiast czystość pośrednia oznacza, że jej skutki będa odczuwalne najczęściej poza miejscem użytkowania taboru szynowego.

W tym drugim przypadku chodzi zwłaszcza o mniejszą emisję dwutlenku węgla przez elektrownię w wyniku zastosowania na budowę i utrzymanie taboru mniej energochłonnych i dających się łatwo utrzymać w eksploatacji materiałom.

Najważniejszymi zagrożeniami bezpośrednimi środowiska (utrzymanie czystości) od strony taboru szynowego z punktu widzenia ekologii będą:

- hałas i drgania

- emisja substancji szkodliwych

- zanieczyszczenia od otwartych instalacji sanitarnych

- zanieczyszczenia produktami eksploatacyjnymi (olejami, smarami, pyłami od klocków i okładzin hamulcowych).

Część dalsza artykuły poświęcona zostanie omówieniu tylko najważniejszych zagrożeń bezpośrednich, które mają największe znaczenie w utrzymaniu czystego środowiska w miastach i obszarach metropolitalnych.

\subsection{Halas i drgania}

Hałasem nazywane są dźwięki o dowolnym charakterze akustycznym, niepożądane i działające za pośrednictwem powietrza na wszystkie organy organizmu człowieka, w tym również słuch, natomiast drganiami akustycznymi nazywamy ruch cząstek środowiska 
sprężystego względem określonego położenia równowagi rozchodzące się w sposób falowy [2].

Drgania i hałas emitowany przez tabor szynowy jest uzależniony przede wszystkim od rodzaju pojazdu i charakteru jego pracy. W przypadku taboru szynowego przeznaczonego do obsługi ruchu pasażerskiego $\mathrm{w}$ miastach i na obszarach metropolitalnych hałas i drgania podczas eksploatacji (również podczas postoju na przystankach i stacjach) emitowane są w sposób ciagły, przy czym jego wartości podczas postoju są znacznie mniejsze.

Przyczynami powstawania hałasu i drgań emitowanych przez tabor szynowy są:

- duża masa pojazdów (w stosunku do pojazdów drogowych)

- duże naciski zestawów kołowych na tor

- stosunkowo duża masa nieusprężynowania (zestawy kołowe, przekładnie, część masy silnika trakcyjnego oparta bezpośrednio na osi zestawu kołowego)

- głośna praca maszyn i urządzeń pomocniczych takich jak sprężarki, wentylatory, silniki napędów pomocniczych oraz maszyny napędów głównych pojazdów, tj. silniki spalinowe, silniki elektryczne, przekładnie główne i osiowe.

Zjawiskiem towarzyszącym hałasowi wywołanemu podczas eksploatacji (w ruchu) pojazdów szynowych są również drgania gruntu będące efektem występowania dużych sił w układzie koło-szyna. Odmienny charakter ma hałas i drgania w metrze, ponieważ oddziaływuje zwłaszcza na obudowę tunelu, co zwiększa ich wielkość. Źródłami ich są drgania i hałas wywołane pracą maszyn i urządzeń, oddziaływaniem dynamicznym zestawu wagonów w wyniku jazdy po torach o małych promieniach oraz tarciem powietrza o obudowę tunelu.

Ważnym jest więc projektowanie pociagów eksploatowanych w metrze o opływowych kształtach bez wystających zbędnych elementów. O ile zalecane (dopuszczalne) wartości hałasu emitowane przede wszystkim na zewnątrz przez pojazd szynowy zostały określone dla elektrycznych i spalinowych zespołów trakcyjnych oraz tramwajów [13, 16, 18], o tyle dla pociagów metra nie ma jasno sprecyzowanych parametrów dopuszczalnych.

$\mathrm{Z}$ pomiarów wykonywanych podczas prób odbiorczych wagonów metra wynika, że podczas przejazdu i odjazdów pociagu hałas osiaga wartość $90 \div 100 \mathrm{~dB}$ (A), a podczas jazdy w samym wagonie nie przekracza wartości $80 \mathrm{~dB}$ (A) [2].

Ponadto nie zostały jasno postawione wymagania $\mathrm{w}$ zakresie dopuszczalnego hałasu we wnętrzach pasażerskich spalinowych i elektrycznych zespołów trakcyjnych oraz tramwajowych. Dopuszczalne (zalecane) wartości hałasu przez poszczególne rodzaje taboru wykorzystywanego w miastach i na obszarach metropolitalnych przedstawiono w tabeli 7 .
Nadmienić należy, że wartości w tabeli 7 odnoszą się nowobudowanego taboru szynowego przed jego dopuszczeniem do ruchu. Dla pojazdów odnawialnych i modernizowanych poziom hałasu zgodnie z wymaganiami [13] nie może być powiększony w stosunku do charakterystyki przed modernizacją.

Walka z hałasem i drganiami jest skomplikowana zwłaszcza że nie wszystko zależy od samego taboru. Nie mniej jednak prowadzone są działania mające na celu obniżenie hałasu i drgań w nowym i modernizowanym taborze szynowym.

Do najważniejszych działań należą:

- wprowadzenie nowych materiałów dźwiękochłonnych (dla ograniczenia hałasu wewnętrznego i zewnętrznego emitowanego przez silniki spalinowe i maszyny pomocnicze)

- wymiana zespołów emitujących wysoki hałas $\mathrm{i}$ drgania, np. zastapienie sprężarek tłokowych sprężarkami śrubowymi

- zastosowanie elementów elastycznych do posadowienia głównych zespołów oraz ekranowanie akustyczne tych zespołów, np. kontenery zamknięte $\mathrm{z}$ agregatami sprężarkowymi w elektrycznych zespołach trakcyjnych

- zastosowanie sztywnych konstrukcji obniżających drgania elementów takich jak drzwi, poszycia, przegrody, dachy, okna

- stosowanie hamulców elektrodynamicznych (elektrycznych) i hydrodynamicznych

- stosowanie układów przeciwpoślizgowych (przy hamowaniu)

- optymalizacja kształtu pojazdu - stosowanie osłon odbieraków prądu, osłon od spodu pojazdu, osłon układów biegowych (wózków) - rys.4 $\div 11$

- stosowanie usprężynowanych kół w tramwajach

- stosowanie nowoczesnych systemów napędowych oraz elementów zawieszenia i usprężynowania.

Należy również stwierdzić, że bardzo duże znaczenie na emisję drgań i hałasu oprócz budowy pojazdu szynowego na jego stan techniczny ma prędkość ruchu oraz natężenie i płynność ruchu, a ponadto stan torowiska i podtorza.

\subsection{Emisja substancji szkodliwych (toksycznych) przez spalinowe pojazdy trakcyjne}

Zdecydowana większość materiałów eksploatacyjnych ma niekorzystny wpływ na środowisko naturalne w całym swoim cyklu użytkowania, tj. od produkcji do recyklingu lub utylizacji. Jednakże największe zagrożenia środowiska naturalnego można spodziewać się od olejów silnikowych stosowanych jako paliwa do silników z zapłonem samoczynnym wykorzystywanym do napędu spalinowych zespołów trakcyjnych oraz spalinowych autobusów szynowych. 
Dopuszczalne (zalecane) wartości hałasu emitowane przez pojazdy szynowe [13, 18],

\begin{tabular}{|c|c|c|c|}
\hline \multirow[b]{2}{*}{ Parametr [dB (A)] } & $\begin{array}{l}\text { Elektryczny zespół } \\
\text { trakcyjny }\end{array}$ & $\begin{array}{l}\text { Spalinowy zespól } \\
\text { trakcyjny }\end{array}$ & \multirow{2}{*}{ Tramwaj } \\
\hline & \multicolumn{2}{|c|}{$\begin{array}{c}\text { 7,5 m od osi toru na wysokości } 1,2 \mathrm{~m} \\
\text { od poziomu główki szyny }\end{array}$} & \\
\hline Hałas stacjonarny & 68 & 73 & $\begin{array}{c}70 \\
\text { (3 m od ściany wagonu } \\
\text { na wysokości } 1,6 \mathrm{~m} \\
\text { od poziomu główki } \\
\text { szyny) }\end{array}$ \\
\hline Hałas podczas ruszania & 82 & $\begin{array}{l}83-\mathrm{P}<500 \mathrm{~kW} / \text { silnik } \\
85-\mathrm{P}>500 \mathrm{~kW} / \text { silnik }\end{array}$ & - \\
\hline $\begin{array}{l}\text { Hałas dla zespołu podczas przejaz- } \\
\text { du z prędkością } 80 \mathrm{~km} / \mathrm{h}\end{array}$ & 81 & 82 & - \\
\hline $\begin{array}{l}\text { Hałas dla tramwaju podczas prze- } \\
\text { jazdu z prędkością } 50 \mathrm{~km} / \mathrm{h}\end{array}$ & - & - & $\begin{array}{c}88 \\
\text { (7,5 m od osi toru na } \\
\text { wysokości } 1,6 \mathrm{~m} \text { od } \\
\text { poziomu główki szyny) }\end{array}$ \\
\hline $\begin{array}{l}\text { Hałas wewnętrzny w kabinie na } \\
\text { postoju }\end{array}$ & 95 & 95 & - \\
\hline $\begin{array}{l}\text { Hałas wewnętrzny w kabinie dla } \\
\text { prędkości max. }<190 \mathrm{~km} / \mathrm{h}\end{array}$ & 78 & 78 & - \\
\hline
\end{tabular}

Dopuszczalne wartości emisji składników toksycznych spalin w [g/kWh] dla silników spalinowych wagonów motorowych $[14,15,17]$.

Tabela 8

\begin{tabular}{|l|c|c|c|c|c|}
\hline $\begin{array}{r}\text { Emisja } \\
{[\mathbf{g} / \mathbf{k W h}]}\end{array}$ & $\begin{array}{c}\text { Tlenek węgla } \\
\text { CO }\end{array}$ & $\begin{array}{c}\text { Węglowodory } \\
\text { HC }\end{array}$ & $\begin{array}{c}\text { Suma } \\
\text { Tlenki azotu } \\
\text { NO }\end{array}$ \\
$\begin{array}{l}\text { Etap i data } \\
\text { wprowadzenia } \\
\text { (obowiązywania) }\end{array}$ & $\begin{array}{c}\text { wewodorów } \\
\text { i tlenków azo- } \\
\text { tu } \\
\text { HC+NO }\end{array}$ & $\begin{array}{c}\text { Cząstki stałe } \\
\text { (PM) }\end{array}$ \\
\hline $\begin{array}{l}\text { Etap III A dla silników wagonów } \\
\text { silnikowych (po 31.12.2005r.) } \\
\text { P>130 kW }\end{array}$ & 3,5 & - & - & 4,0 & 0,2 \\
\hline $\begin{array}{l}\text { Etap III B dla silników wagonów } \\
\text { silnikowych (po 31.12.2011r.) } \\
\text { P>130 kW }\end{array}$ & 3,5 & 0,19 & 2,0 & - & 0,025 \\
\hline
\end{tabular}

Dopuszczalne wartości emisji składników toksycznych spalin $\mathbf{w}[\mathrm{g} / \mathrm{kW}]$ dla spalinowych silników samochodowych z zapłonem samoczynnym o mocach powyżej $85 \mathrm{~kW}$ wykorzystywanych w lekkich pojazdach szynowych [7].

Tabela 9

\begin{tabular}{|c|c|c|c|c|c|c|}
\hline \multicolumn{2}{|r|}{$\begin{array}{c}\text { [g/kWh] } \\
\text { Data wprowadzenia (oboviązy- } \\
\text { wania) }\end{array}$} & $\begin{array}{c}\text { Tlenek wę- } \\
\text { gla } \\
\text { CO }\end{array}$ & $\begin{array}{c}\text { Węglowodory } \\
\mathbf{C H}\end{array}$ & $\begin{array}{c}\text { Tlenki azotu } \\
\mathbf{N O}_{\mathbf{x}}\end{array}$ & $\begin{array}{c}\text { Cząstki stałe } \\
\text { PM }\end{array}$ & $\begin{array}{c}\text { Zadymienie } \\
{\left[\mathbf{k}^{-\mathbf{1}}\right]}\end{array}$ \\
\hline Euro I & 01.01 .1992 & 4,5 & 1,10 & 8,0 & 0,612 & - \\
\hline \multirow{2}{*}{ Euro II } & 01.10 .1996 & 4,0 & 1,10 & 7,0 & 0,250 & - \\
\cline { 2 - 7 } & 01.10 .1998 & 4,0 & 1,10 & 7,0 & 0,150 & - \\
\hline \multirow{2}{*}{ Euro III } & 01.01 .1999 & 1,5 & 0,25 & 2,0 & 0,020 & 0,15 \\
\hline Euro IV & 01.10 .2000 & 2,1 & 0,66 & 5,0 & 0,100 & 0,80 \\
\hline Euro V & 01.10 .2005 & 1,5 & 0,46 & 2,0 & 0,020 & 0,50 \\
\hline
\end{tabular}


Głównymi źródłami zanieczyszczającymi atmosferę przez silniki spalinowe są:

- układ wylotowy

- skrzynia korbowa oraz jej układy odpowietrzania i filtrowania

- układ paliwowy, w tym zbiorniki paliwa i ich układy odpowietrzajace

przy czym podstawowym źródłem zanieczyszczeń jest układ wylotowy, który emituje największe ilości związków toksycznych do atmosfery.

Podstawowymi związkami toksycznymi emitowanymi przez silniki spalinowe należą: tlenek węgla (CO), węglowodory (HC), tlenki azotu $\left(\mathrm{NO}_{\mathrm{x}}\right)$, aldehydy (RCHO), dwutlenek siarki $\left(\mathrm{SO}_{2}\right)$, związki ołowiu oraz cząstki stałe (w tym sadza).

Do najgroźniejszych (emitowanych w większych ilościach) w eksploatacji spalinowych pojazdów szynowych, które badane są przed ich dopuszczeniem do ruchu (najcześniej po przeprowadzonych zabiegach modernizacyjnych) należą $\mathrm{CO}, \mathrm{HC}, \mathrm{NO}_{\mathrm{x}}$ oraz $\mathrm{PM}$ (cząstki stałe).

Przyczynami głównymi powstawania najgroźniejszych związków toksycznych wydalanych przez układy wylotowe są [11]:

- dla emisji tlenku węgla (CO) - lokalny lub globalny niedobór tlenku w procesie spalania, niska temperatura (niedogrzanie) silnika, niski poziom turbolencji i małe zawirowania oraz recykulacja spalin

- dla emisji węglowodorów (HC) - brak wystarczającej ilości powietrza (tlenu), wypadanie zapłonu, efekty przyścienne i szczelinowe (luzy w układzie tłok-cylinder), parowanie oleju napędowego oraz proces przepukiwań cylindrów świeżą mieszanką

- dla emisji tlenków azotu $\left(\mathrm{NO}_{\mathrm{x}}\right)$ - wzrost maksymalnej temperatury spalania, niewłaściwy stosunek powietrza do oleju napędowego oraz małe obciążenie silnika związane $\mathrm{z}$ istnieniem tzw. stref chłodnych

- dla emisji cząstek stałych (PM) - ścieranie elementów silnika (para cierna cylinder-tłok), zanieczyszczenia zawarte $\mathrm{w}$ oleju napędowym, utlenianie i koksowanie oraz powstawanie sadzy w procesie spalania i wylotu.

W związku z coraz większą emisją związków toksycznych do atmosfery związane $\mathrm{z}$ rozwojem transportu drogowego i szynowego wykorzystującego do napędu silniki spalinowe wprowadzone zostały coraz ostrzejsze wymagania w zakresie dopuszczalnych wartości emisji najgroźniejszych składników toksycznych wydalanych wraz ze spalinami do atmosfery.

Opracowane na podstawie dyrektyw i rozporządzeń $[7,14,15,17]$ dopuszczalne wartości emisji składników toksycznych spalin dla silników spalinowych wykorzystywanych do napędu spalinowych zespołów trakcyjnych i autobusów szynowych z napędem spalinowym przedstawiono w tabelach 8 i 9 .

Mimo to, że udział trakcji spalinowej w ogólnym zanieczyszczeniu atmosfery w stosunku do pojazdów drogowych jest nieznaczny, a biorąc pod uwagę to, że udział spalinowych zespołów trakcyjnych eksploatowanych w miastach i na obszarach metropolitalnych (w ogólnej liczbie spalinowych pojazdów trakcyjnych) nie przekracza $2 \%$, prowadzone są prace nad redukcją związków toksycznych wydalanych w spalinach dla wszystkich spalinowych pojazdów trakcyjnych.

Podstawowe działania prowadzone dla zmniejszenia emisji związków toksycznych do atmosfery (niezależnie od pojazdów, w których zastosowano silniki spalinowe) są następujące $[8,9]$ :

- stosowanie nowoczesnych silników spalinowych spełniających dopuszczalne wartości emisji składników toksycznych do atmosfery

- stosowanie czystych paliw wydzielających w procesie spalania mniejsze ilości związków toksycznych i $\mathrm{CO}_{2}$ (paliwa gazowe - gaz ziemny, propan-butan, wodór; paliwa ciekłe - oleje roślinne, alkohole, metanol, etanol; paliwa syntetyczne)

- optymalizacja procesu spalania w silnikach spalinowych tak, aby minimalizować ilość związków toksycznych $\left(\mathrm{CO}, \mathrm{HC}, \mathrm{NO}_{\mathrm{x}}, \mathrm{SO}_{2}\right.$, aldehydy, związki ołowiu, cząstki stałe) oraz $\mathrm{CO}_{2} \mathrm{w}$ spalinach

- usuwanie związków toksycznych ze spalin opuszczających silnik spalinowy (zastosowanie katalizatorów i filtrów cząstek stałych)

- wprowadzenie napędów hybrydowych typu mieszanego, tzn. spalinowo-elektrycznych wykorzystujących silniki elektryczne podczas ruszania, silnik spalinowy podczas jazdy z stałą prędkością, a podczas hamowania wykorzystania w ładowaniu akumulatorów.

Mimo to, że zastosowanie reaktorów, filtrów i katalizatorów w szynowych pojazdach $\mathrm{z}$ napędem spalinowym może być obecnie nieopłacalne na rys.26 przedstawiono sposoby i możliwe do uzyskania efekty dla redukcji najgroźniejszych związków toksycznych emitowanych do atmosfery [8].

Dla silników spalinowych (najczęściej małej mocy) wykorzystywanych w pojazdach spalinowych przewidzianych do eksploatacji w większości obszarów metropolitalnych należałoby dla ograniczenia emisji związków toksycznych w spalinach przeprowadzić następujące przedsięwzięcia przedstawione $\mathrm{w}$ tabeli 10.

Przedsięwzięcia stosowane w silnikach małej mocy (najczęściej wykorzystywane w budowie lekkich pojazdów szynowych typu autobus szynowy) z zapłonem samoczynnym w celu zmniejszenia toksyczności spalin $[2,11]$. 
Tabela 10

\begin{tabular}{|c|c|c|}
\hline L.p. & Rodzaj przedsięwzięcia & Korzyści \\
\hline 1. & Wzrost stopnia zawirowania & $\begin{array}{l}\text { Skrócenie czasu spalania i opóźniania samozapłonu oraz zmniej- } \\
\text { szenie emisji PM, HC, CO }\end{array}$ \\
\hline 2. & $\begin{array}{l}\text { Optymalizacja kształtu strugi i umiesz- } \\
\text { czenie wtryskiwacza w komorze spala- } \\
\text { nia }\end{array}$ & $\begin{array}{l}\text { Skrócenie czasu spalania, opóźnienia samozapłonu, zmniejszenie } \\
\text { emisji PM }\end{array}$ \\
\hline 3. & Zwiększenie wtrysku paliwa & Skrócenie czasu opóźnienia samozapłonu, zmniejszenie emisji PM \\
\hline 4. & Elektronizacja wtrysku paliwa & $\begin{array}{l}\text { Optymalizacja kąta wyprzedzenia wtrysku (uzależnienie od więk- } \\
\text { szej liczby parametrów pracy) }\end{array}$ \\
\hline 5. & Opóźnienie wtrysku paliwa & Obniżenie emisji $\mathrm{NO}_{\mathrm{x}}$ \\
\hline 6. & Wtrysk z dawką pilotującą & $\begin{array}{l}\text { Skrócenie czasu opóźnienia samozapłonu, zmniejszenie emisji PM, } \\
\text { zmniejszenie szybkości przyrostu ciśnienia } \mathrm{dp} / \mathrm{d} \alpha \text { (hałaśliwość) }\end{array}$ \\
\hline 7. & Doładowanie & $\begin{array}{l}\text { Obniżenie emisji wszystkich składników toksycznych i wzrost } \\
\text { sprawności ogólnej }\end{array}$ \\
\hline 8. & Chłodzenie powietrza doładowanego & Zwiększenie efektów wynikających z doładowania \\
\hline 9. & Recyrkulacja spalin & Obniżenie emisji $\mathrm{NO}_{\mathrm{x}}$ \\
\hline 10. & Głowice wielozaworowe & Wzrost stopnia napełniania, zmniejszenie zużycia paliwa \\
\hline 11. & $\begin{array}{l}\text { Elektroniczna regulacja faz rozrządu i } \\
\text { wzniosu zaworów }\end{array}$ & $\begin{array}{l}\text { Poprawa stopnia napełnienia, zmniejszenie emisji } \mathrm{NO}_{\mathrm{x}} \text { przez ste- } \\
\text { rowanie zamknięciem zaworu wylotowego }\end{array}$ \\
\hline 12. & Ograniczenie zużycia oleju & $\begin{array}{l}\text { Obniżenie emisji PH i HC (PAH - wielopierścieniowe węglowodo- } \\
\text { ry aromatyczne) }\end{array}$ \\
\hline 13. & Katalizator utleniający & Obniżenie emisji PM, HC i CO \\
\hline 14. & Filtry sadzowe & Obniżenie emisji PM i częściowo HC \\
\hline 15. & $\begin{array}{l}\text { Urządzenia skracające czas nagrzewa- } \\
\text { nia silnika }\end{array}$ & Obniżenie toksyczności podczas nagrzewania silnika \\
\hline 16. & $\begin{array}{l}\text { Stosowanie paliw o zmniejszonej za- } \\
\text { wartości siarki }\end{array}$ & Zmniejszenie emisji związków siarki, obniżenie emisji PM \\
\hline
\end{tabular}

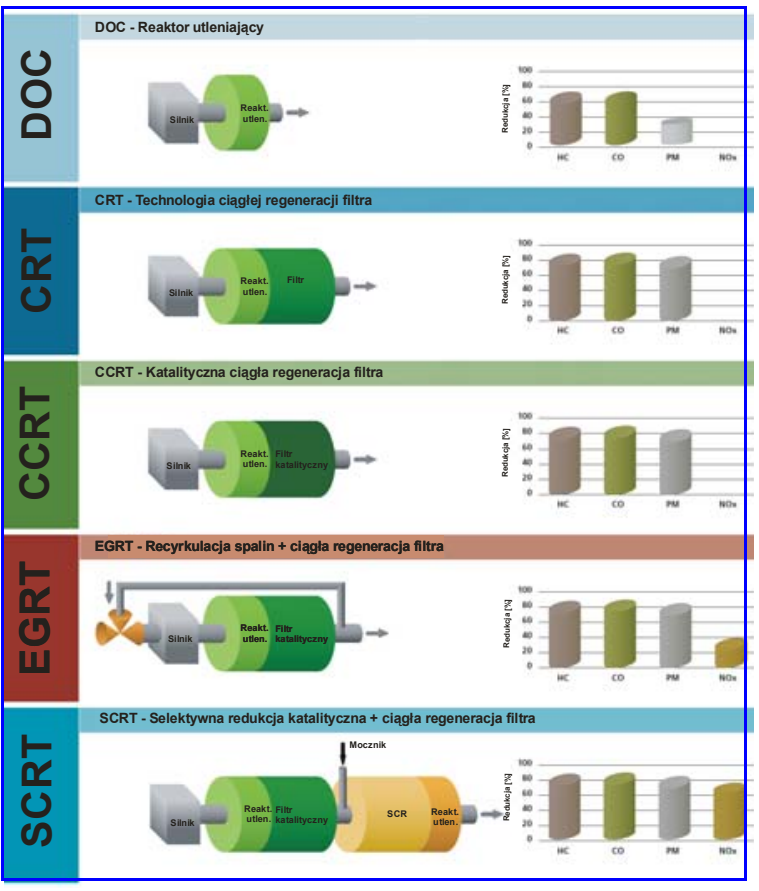

Rys.26 - Sposoby i możliwe do uzyskania efekty redukcji emisji związków toksycznych zawartych w spalinach do atmosfery $\mathrm{w}$ wyniku stosowania reaktorów, filtrów i katalizatorów

DOC - reaktor utleniajacy

$C R T$ - technologia ciagłej regeneracji filtra

$C C R T$ - katalityczna ciagta regeneracja filtra

EGRT - recyrkulacja spalin + ciagła regeneracja filtra

$S C R T$ - selektywna redukcja katalityczna + ciagła regeneracja filtra.
Ponieważ w kraju jest eksploatowana duża liczba pojazdów spalinowych przeznaczonych do ruchu $\mathrm{w}$ obszarach metropolitalnych, w których zastosowano starszego typu silniki spalinowe, koniecznym staje się przy każdej naprawie dokonywać prac regulacyjnowymiennych, które zdecydowanie zmniejszą emisję związków toksycznych do atmosfery.

Poprawę emisji dla poszczególnych najniebezpieczniejszych związków toksycznych można osiagnąć poprzez $[8,9]$ :

- dla tlenku węgla (CO) - wymianę lub jeżeli to możliwe regulację wtryskiwaczy oraz utrzymanie współczynnika nadmiaru powietrza (przez ustawienie właściwego ciśnienia doładowania) na prawidłowym poziomie $\mathrm{w}$ warunkach mocy maksymalnej

- dla węglowodorów (HC) - sprawdzenie i regulacja wtryskiwaczy (pojedynczo lub kompleksowo) oraz sprawdzenie ciśnienia sprężania (indykowanie silnika) eliminując wymianę układów tłok-cylinder-pierścienie (przy braku właściwych parametrów należy wymienić układ tłokowy)

- dla tlenków azotu $\left(\mathrm{NO}_{\mathrm{x}}\right)$ - zmianę opóźnienia kąta początku wtrysku oleju napędowego, utrzymanie ciśnienia początku wtrysku powyżej norm regulacyjnych oraz właściwa regulacja ciśnienia doładowania 
- dla cząstek stałych (PM) - regulację układów recyrkulacji spalin oraz wyposażenie silników w układy oczyszczania spalin.

Działanie prowadzące do poprawy w zakresie emisji związków toksycznych do atmosfery przez silniki spalinowe są kosztowne, jednak uzyskane efekty będa miały duże znaczenie w udziale w niszczeniu atmosfery (środowiska naturalnego).

\subsection{Zanieczyszczenia materialami eksploatacyj- nymi i otwartymi instalacjami sanitarnymi}

Materiały eksploatacyjne (z wyłączeniem olejów napędowych stosowanych do napędu silników spalinowych) wykorzystane w eksploatacji i utrzymany pojazdów szynowych, to przede wszystkim płyny chłodzące, oleje hydrauliczne, płyny do spryskiwaczy szyb, oleje lub smary dla układów smarowania obrzeży kół oraz środki myjąco-czyszczące stosowane w utrzymaniu czystości wewnętrznej i zewnętrznej.

Mimo tego, że ich udział w zanieczyszczeniu środowiska naturalnego (dla pojazdów eksploatowanych na terenie miast $\mathrm{i}$ na obszarach metropolitalnych) jest obecnie nieznacznie, to jednak wraz $\mathrm{z}$ rozwojem transportu szynowego udział ich może wzrastać i dlatego należy dążyć przede wszystkim do:

- stosowania materiałów biodegradowalnych, np. olejów do smarowania obrzeży kół, płynów do spryskiwaczy

- stosowania szczelnych układów zawierających płyny eksploatacyjne

- stosowania trwałych i niezawodnych uszczelnień w układach chłodzących i napędach hydraulicznych

- przestrzegania okresów wymiany płynów i materiałów eksploatacyjnych („starzenie” powoduje zmiany jakościowe wpływające na wzrost zanieczyszczeń)

- stosowania zamkniętych systemów wykorzystania płynów czyszczących użytkowanych w procesie czyszczenia i mycia pojazdów

- stosowania płynów chłodzących nietoksycznych, niepalnych, łatwych w utylizacji, np. mieszaniny wody z glikolem monopropylanowym (w miejsce toksycznego glikolu etylowego)

- właściwej organizacji odbioru „przepracowanych" płynów eksploatacyjnych zwłaszcza smarów i olejów.

Stosowane w większości elektrycznych i spalinowych zespołów trakcyjnych instalacje sanitarne są systemami otwartymi co powoduje szereg niedogodności technicznych i niekorzystnie wpływa na środowisko naturalne. Najważniejsze niedogodności to brak możliwości użytkowania podczas postoju, duże zabrudzenia podwozia i nieprzyjemne zapachy zniechęcające podróżnych do korzystania z nich.
Dla poprawy i redukcji zanieczyszczeń związanych ze stosowania toalet typu otwartego jest tylko jedno skuteczne wyjście tzn. zastosowanie systemów akumulacyjnych, czyli wprowadzenie toalet pracujących w cyklu zamkniętym. Polega to na tym, że toaleta wyposażona jest $\mathrm{w}$ zbiornik, w którym następuje gromadzenie nieczystości, który następnie zostaje opróżniony (na stacjach końcowych lub macierzystych) metodą grawitacyjną, podciśnieniową lub ciśnieniową.

Proponowane przez różne zarządy kolejowe metody zamrażania lub spalania nieczystości są obecnie energochłonne, co wpływa na pogorszenie efektu cieplarnianego [2].

Przykłady toalet pracujących w układach zamkniętych i stosowanych w nowych lub zmodernizowanych pojazdach szynowych eksploatowanych na obszarach metropolitalnych zaprezentowano na rys. $27 \div 29$.

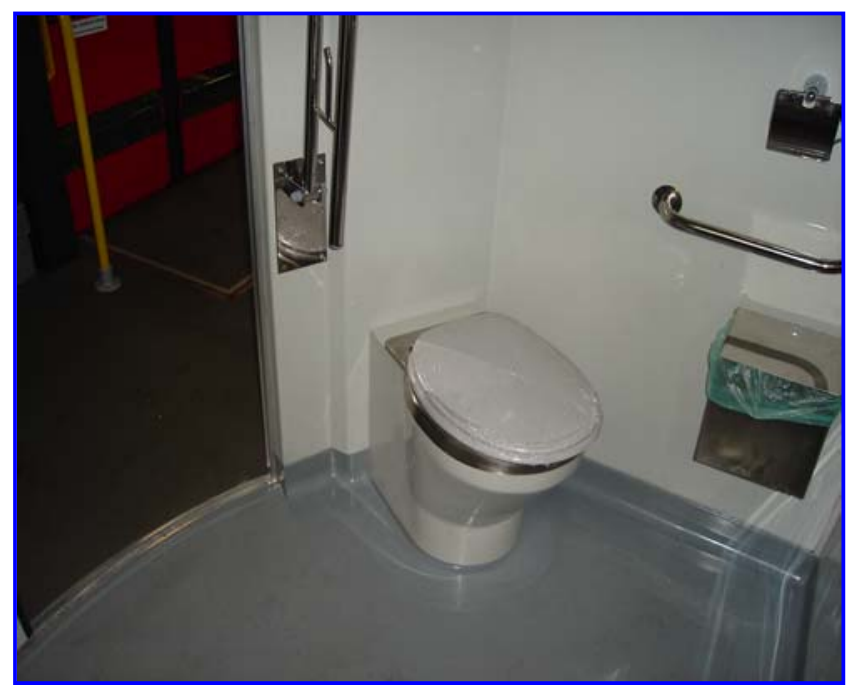

Rys.27 - Widok na toalety WC zastosowaną w spalinowym autobusie szynowym serii SA108

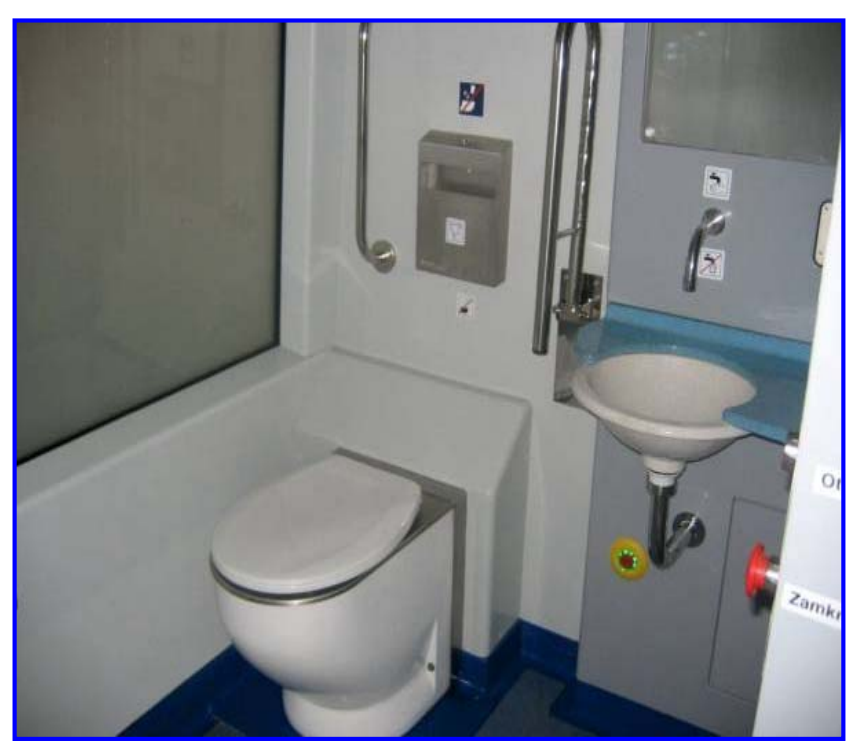

Rys.28 - Widok na toaletę WC zastosowaną w elektrycznym autobusie szynowym Serii EN81 


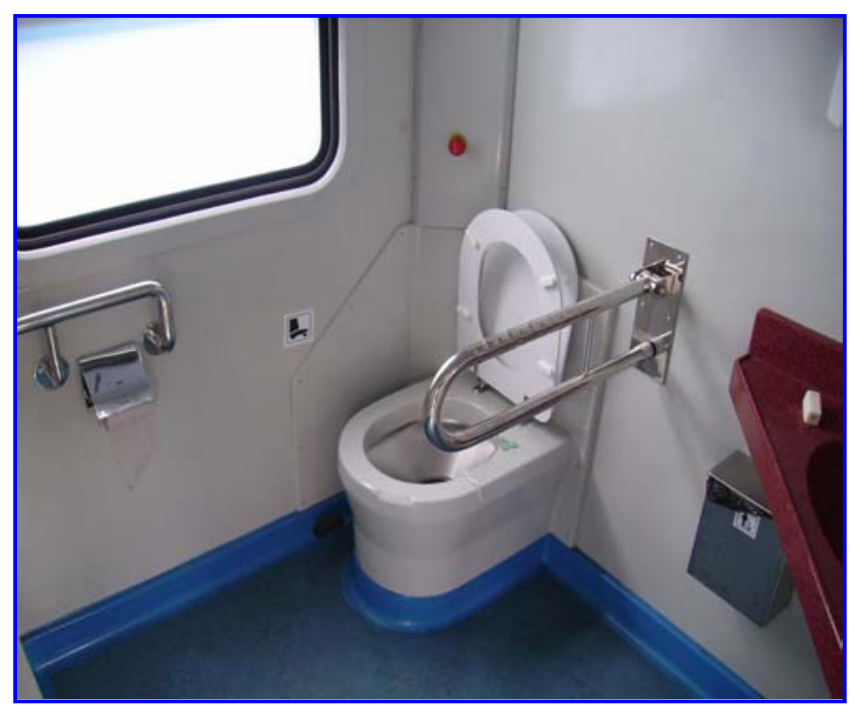

Rys.29 - Widok na toaletę WC przystosowaną do obsługi osób niepełnosprawnych zastosowaną w zmodernizowanych ezt EN57

\subsection{Czynniki wpływające na środowisko w ujęciu zagrożeń (czystości) pośrednich}

Czystość środowiska naturalnego ma również ścisły związek z wytwarzaniem i rozprowadzeniem emisji. Tak więc oszczędności energii rozumiane jako działania prowadzące do jej zmniejszenia zarówno na etapie budowy i modernizacji taboru szynowego jak i w procesie eksploatacji ma bardzo duże znaczenie $\mathrm{w}$ „walce” z tzw. efektem cieplarnianym, a więc ograniczeniem emisji do atmosfery dwutlenku węgla.

Wśród wielu czynników wpływających na obniżenie emisji dwutlenku węgla do atmosfery, na który wpływ ma budowa i eksploatacja pojazdu szynowego zaliczyć należy [12]:

- masę własną pojazdu

- strukturę materiałowa

- bilans energetyczny

- zdolność do recyklingu i utylizacji.

$\mathrm{Na}$ masę własną pojazdu wpływ mają przede wszystkim zastosowane materiały. Im mniejsza ich masa, tym mniejsza ilość energii niezbędna do ich wytwarzania. Natomiast stosowanie materiałów łatwych w utrzymaniu, wytrzymałych, o niewielkim stopniu starzenia $\mathrm{w}$ całym procesie eksploatacji oraz materiałów pozwalających na pełny recykling i utylizację jak również pełna optymalizacją konstrukcji prowadzić będzie również do oszczędności energii.

Również duża sprawność układów napędowych, dostosowanie charakterystyki pojazdu do zamierzonych i przewidywanych zadań przewozowych, zmniejszenie oporów aerodynamicznych i toczenia, a ponadto wykorzystanie ciepła pochodzącego $\mathrm{z}$ układu chłodzenia silnika spalinowego do ogrzewania wnętrza pojazdów ma wpływ na bilans energetyczny, a więc również na zużycie energii elektrycznej.

Ważnym jest również recykliny i utylizacja wykorzystywanych w budowie i modernizacji, a przede wszystkim w eksploatacji materiałów, olejów, smarów i płynów, które można powtórnie wykorzystać zarówno po przeróbce lub po rozdzieleniu i segregacji.

Zastosowanie w/w wymagań pozwala na oszczędności do $30 \%$ energii, a więc do obniżenia emisji $\mathrm{CO}_{2}$. Natomiast recykliny materiałów użytych $\mathrm{w}$ procesie produkcji i eksploatacji może sięgnąć nawet do $95 \%$. W procesie budowy, modernizacji i eksploatacji pojazdów szynowych znaleźć można wiele przykładów ograniczających emisję dwutlenku węgla do atmosfery. Jednym $\mathrm{z}$ nich jest zastosowanie $\mathrm{w}$ tramwajach mobilnych zasobników energii dla magazynowania „energii hamowania” i przekazywania jej do sieci. Może to być zużyte na cele trakcyjne, np. na terenie zajezdni [10].

Przykład zastosowania mobilnego zasobnika przedstawiono na rys.30.

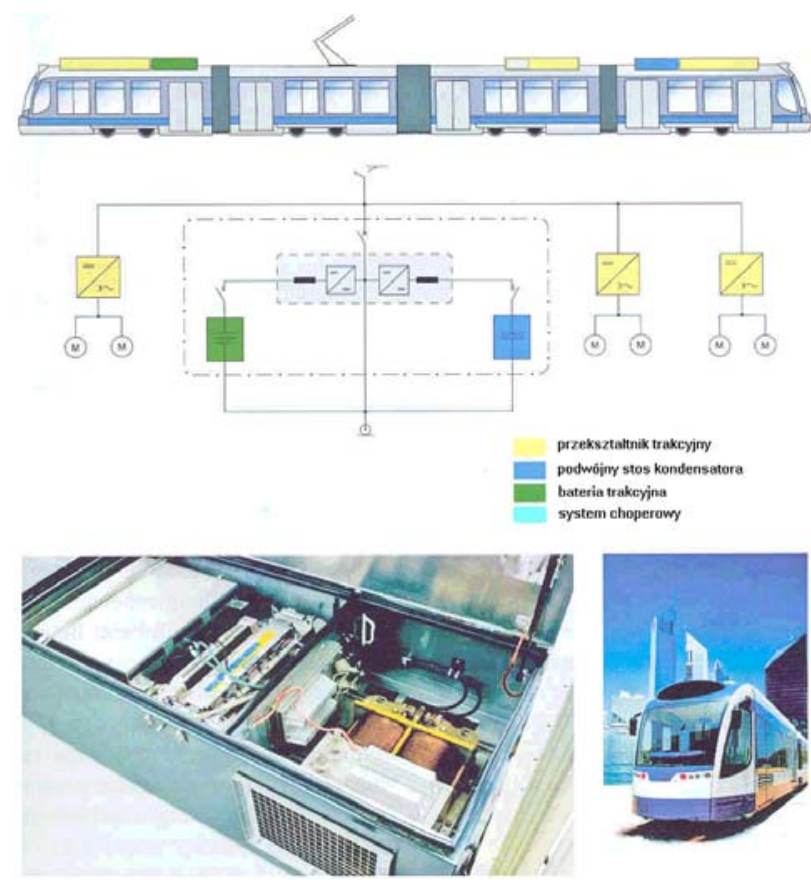

Rys.30 - Zasada zastosowania mobilnego zasobnika energii dla zasilania tramwaju Combino

\section{Podsumowanie}

W kraju w ostatnich latach buduje się coraz więcej nowoczesnych i ekologicznych pojazdów szynowych. Ponadto procesy modernizacyjne taboru szynowego coraz bardziej ukierunkowane są na wykorzystanie aparatów, urządzeń i zespołów o minimalnym szkodliwym oddziaływaniu na środowisko. Dotyczy to również taboru zakupowanego za granicą. Przestrzeganie określonych reguł i zaleceń dyrektyw europejskich i rozporządzeń krajowych oraz norm europejskich i krajowych, to coraz mniejsza emisja związków toksycznych do atmosfery, mniejszy hałas i drgania oraz mniejsza ilość pyłów i innych zanieczyszczeń pochodzących od materiałów eksploatacyjnych. 
Bardzo ważnym jest nie tylko budowa i modernizacja taboru szynowego, ale również warunki jego eksploatacji oraz „zdolność” po jej zakończeniu do recyklingu i utylizacji materiałów używanych w budowie $\mathrm{i}$ modernizacji. Im wyższy procent tej zdolności, tym mniej energii na ich wytworzenie co skutkować będzie mniejszą emisją dwutlenku węgla do atmosfery decydującym o tzw. efekcie cieplarnianym.

$\mathrm{W}$ budowie i modernizacji należy więc:

- dla zmniejszenia emisji związków toksycznych stosować nowoczesne silniki spalinowe, a jednocześnie przestrzegać zasad eksploatacyjnych prowadząc przeglądy, regulacje, wymiany materiałów eksploatacyjnych zgodnie $\mathrm{z}$ zaleceniami

- dla ograniczenia emisji pyłów należałoby wykorzystać najnowsze osiagnięcia energoelektroniki wprowadzając między innymi nowoczesne impulsowe układy sterowania, układy rekuperacji (odzysku) energii oraz układy przeciwpoślizgowe

- dla ograniczenia hałasu i drgań należy stosować między innymi nowoczesne materiały wygłuszające i thumiące, elementy elastyczne w mocowaniach, sztywne konstrukcje pudeł.

Bardzo istotnym problemem dla nas jest sprowadzanie do kraju przestarzałego taboru, którego oddziaływanie na środowisko jest zbyt duże. Tabor ten przekazywany w darze lub sprzedawany za symboliczna cenę może w niedalekiej przyszłości być niewygodny dla obecnych użytkowników, ponieważ koszty recyklingu i utylizacji mogą znacznie przekroczyć zyski uzyskane z eksploatacji.

Proces budowy i modernizacji taboru szynowego $\mathrm{z}$ punktu widzenia wpływu na środowisko naturalne należy dokonywać w sposób rozważny. Każde przedsięwzięcie winno być opłacalne tzn. wymiana taboru na nowy i modernizacja posiadanego taboru winny być realizowane równolegle.

Artykuł zarysował tylko niektóre najważniejsze zagrożenia od strony taboru, wskazał niektóre przedsięwzięcia jakie należy dokonywać dla zmniejszenia jego niekorzystnego oddziaływania na środowisko.

Efekty z eksploatacji nowego i modernizowanego taboru szynowego są już zauważalne w miejscach jego eksploatacji, a więc w miastach i na obszarach metropolitalnych. Przecież nic nie jest tak ważne jak czyste i zdrowe powietrze oraz mniejszy hałas na ulicach miast i w otoczeniu eksploatowanego taboru.

\section{Literatura}

[1] Biliński J., Marciniak Z.: Modernizacja krajowych elektrycznych zespołów trakcyjnych do obstugi ruchu aglomeracyjnego i podmiejskiego. Materiaty XVIII Konferencji Naukowej Pojazdy Szynowe. Katowice-Ustroń 2008.
[2] Gronowicz J.: Ochrona środowiska w transporcie ladowym. Wydawnictwo Instytutu Technologii Eksploatacji w Radomiu, 2004.

[3] Lubka A., Stiasny M.: Atlas tramwajów. Poznań, 2004.

[4] Marciniak Z.: Modernizacja elektrycznych zespołów trakcyjnych serii EN57, EN71 i EW60. Stan obecny $i$ zamierzenia. Pojazdy Szynowe, nr 1/2009.

[5] Marciniak Z.: Modernizacja spalinowych zespołów trakcyjnych typu MR/MRD i Y do obstugi ruchu regionalnego. Materiaty XVIII Konferencji Naukowej Pojazdy Szynowe. Katowice-Ustroń, 2008.

[6] Marciniak Z.: Konstrukcja i badania spalinowych zespotów trakcyjnych typu MR/MRD i Y do obstugi ruchu aglomeracyjnego $i$ regionalnego. Pojazdy Szynowe, $n r$ $2 / 2009$.

[7] Marciniak Z., Pielecha I.: Wpływ silników spalinowych pojazdów trakcyjnych eksploatowanych $w$ kraju na środowisko - próby $i$ badania oraz wytyczne dla redukcji emisji sktadników szkodliwych. Pojazdy Szynowe, $n r$ $1 / 2009$.

[8] Marciniak Z., Pielecha I.: Wymagania w zakresie ograniczenia emisji toksycznych składników spalin przez spalinowe pojazdy trakcyjne. Technika Transportu, nr 11-12/2006.

[9] Marciniak Z., Pielecha I.: Właściwości silników spalinowych $w$ aspekcie ochrony środowiska. Technika Transportu Szynowego $n r$ 5-6/2008.

[10] Meinert M.: Einsatz neuer Energiespeicher auf Strassenbahnen. ZEVrail 132/2008.

[11] Merkisz J.: Ekologiczne aspekty stosowania silników spalinowych. Wydawnictwo Politechniki Poznańskiej, Poznań 1994.

[12] Struckl W.M., Miltner T., Gunselmann W.: Umweltgerechte Schienenfahrzeugehtwicklung an Beispiel der Metro Oslo ZEVrail 132/2008.

[13] Decyzja Komisji z dnia 23.12.2005 dotyczqca technicznej specyfikacji dla interoperacyjności odnoszqcej się do podsystemu ,tabor kolejowy - hatas “ transeuropejskiego systemu kolei konwencjonalnych - 2006/66/WE.

[14] Dyrektywa 97/68/EC Parlamentu Europejskiego i Rady w sprawie zbliżenia ustawodastwa Państw Członkowskich odnoszacych się do środków dotyczacych ograniczenia emisji zanieczyszczeń gazowych $i$ pyłowych z silników spalinowych montowanych $w$ maszynach samojezdnych poruszajacych sie po drogach, 16.12.1997.

[15] Directive 2004/26/EC of the European Parlament and of the Council amending Directive 97/68/EC on the approximation of the laws of the Member States realting to measures against the emission of gaseous and parliculate pollutants from internal combustion engines to be installed in non-road nobile machinery. 21.04.2004.

[16] Rozporzadzenie Ministra Infrastruktury $z$ dnia 28.12. $2003 w$ sprawie warunków technicznych tramwajów $i$ trolejbusów oraz zakresu ich niezbędnego wyposażenia. Dz. U. nr 230 poz. 2301.

[17] Rozporzqdzenie Ministra Gospodarki i Pracy z dnia 19.08.2005 w sprawie szczególowych wymagań dla silników spalinowych $w$ zakresie ograniczenia emisji zanieczyszczeń gazowych i czqstek statych przez te silniki. Dz. U. nr 202 poz. 1681.

[18] Rozporzqdzenie Ministra Środowiska z dnia 14.06.2007 $w$ sprawie dopuszczalnych poziomów hałasu $w$ środowisku. Dz. U. nr 120 poz. 826 . 